\title{
POCZĄTKI PARAFII MATKI BOŻEJ KRÓLOWEJ KORONY POLSKIEJ NA KIJOWSKIM PRZEDMIEŚCIU W BRZEŚCIU NAD BUGIEM
}

Brześć nad Bugiem (białoruskie Брэст, Берасьи̧е) to dawne kresowe miasto polskie na Polesiu, położone u ujścia rzek Muchawiec i Szlajerka do Bugu, połączonego kanałem z dorzeczem Dniepru. Dla odróżnienia od kujawskiego nazywano go pospolicie Brześciem Litewskim. Wzmiankowane w kronikach historycznych już ok. 1019 roku, stanowiło jeden z najstarszych grodów na pograniczu polsko-rusko-litewskim i było początkowo własnością książąt Turowskich, a od 1041 roku przeszło w posiadanie księcia kijowskiego Jarosława Mądrego. Od końca XII wieku Brześć należał do Polski, a w połowie XIII wieku przeszedł w posiadanie książąt wołyńskich. W 1390 roku otrzymał od księcia Witolda prawa miejskie na prawie magdeburskim. Po zawarciu unii brzeskiej w 1596 roku miasto zostało stolicą województwa brzesko-litewskiego, a po ostatnim rozbiorze Polski w 1795 roku przeszło do Rosji. W latach 1919-1939 znalazło się ponownie w granicach Rzeczypospolitej. Po pożarze Pińska w sierpniu 1921 roku stolicę województwa poleskiego przeniesiono do Brześcia Litewskiego, przemianowanego 12 XI 1923 roku na Brześć nad Bugiem. Mieściła się tu siedziba powiatu brzeskiego i sztab Wojskowego Okręgu Korpusu Brześć Litewski ${ }^{1}$

Po II wojnie światowej i zmianie granic Polski Brześć pozostał w ZSRR, w granicach Białoruskiej Republiki Socjalistycznej i stał się centrum administracyjnym obwodu (województwa) brzeskiego położonego w zachodniej części repub-

* Ks. Waldemar Witold Żurek SDB - dr hab. historii Kościoła, prof. KUL, dyrektor Ośrodka Archiwów Bibliotek i Muzeów Kościelnych KUL, e-mail: zurek@kul.lublin.pl

${ }^{1}$ Na mocy decyzji Polskiego Ministerstwa Spraw Wojskowych z dnia 1 VIII 1921 roku utworzono Wojskowy Okręg Korpusu Brześć Litewski. W 1922 roku obszar Polski został podzielony na dziewięć Okręgów Korpusów, wśród których Okręg nr IX otrzymał nazwę „Poleskiego”. W jego skład wchodziły oddziały z województwa białostockiego i nowogródzkiego, północnej części lubelskiego i dużej części województwa poleskiego. Por. Słownik Geograficzny Królestwa Polskiego $i$ innych krajów stowiańskich, red. F. Sulimierski, B. Chlebowski, W. Walewski, t. 1, Warszawa 1880, s. 399-404; W. Bieszanow, Twierdza Brzeska, Warszawa 2012, s. 117. 
liki oraz siedzibą rejonu (powiatu) brzeskiego przy granicy z Polską. Od 1991 roku miasto znajduje się w granicach Republiki Białoruskiej. Obecnie liczy ponad 300.000 mieszkańców (wg danych z 2010 r.). Stanowi ważny ośrodek przemysłowy, węzeł kolejowy i drogowy przy granicy z Polską, port rzeczny i lotniczy oraz ośrodek kultury polskiej na Białorusi. Z punktu widzenia administracji kościelnej należy do diecezji pińskiej, jednej z czterech diecezji obrządku łacińskiego wchodzącej w skład metropolii mińsko-mohylewskiej, obejmującej swym zasięgiem obwód brzeski i homelski.

\section{Geneza parafii}

W latach międzywojennych Brześć Poleski nad Bugiem zarówno obszarem jak i ilością mieszkańców był największym miastem w diecezji pińskiej².

Dotychczasowy kościół parafialny pw. Podwyższenia Świętego Krzyża, ufundowany w XV wieku, nie wystarczał dla potrzeb tutejszych wiernych wyznania rzymskokatolickiego ${ }^{3}$.

${ }^{2}$ Tradycja biskupstwa łacińskiego w Pińsku na Polesiu sięga okresu porozbiorowego Polski. Cesarzowa Katarzyna II ukazem z 27 IX 1795 roku skasowała diecezję łucką, w jej miejsce utworzyła diecezję ze stolicą w Pińsku, która nie otrzymała sankcji kanonicznej Stolicy Apostolskiej. W ramach reorganizacji Kościoła łacińskiego diecezja ta w roku 1798, została skasowana, przywrócono natomiast diecezję łucką, a Pińsk znalazł się w granicach nowo utworzonej diecezji mińskiej. Do następnych zmian doszło po traktacie ryskim z 1921 roku, który podzielił diecezję mińską między Polskę i ZSRR. W granicach Polski znalazło się 9 dekanatów tej diecezji w całości lub częściowo (53 parafie oraz 73 kaplice publiczne). Rezydencją biskupa mińskiego Zygmunta Łozińskiego i instytucji diecezjalnych był wówczas Nowogródek. Katolicy polskiej części diecezji mińskiej stanowili mniejszość etniczną i narodową, stąd biskupi polscy postulowali powiększenie diecezji mińskiej terytorialnie i ludnościowo. Ostatecznie konkordat polski z 10 II 1925 roku stworzył nową diecezję ze stolicą w Pińsku, a terytorium jej ograniczył do posiadłości diecezji mińskiej w granicach Polski. Na skutek starań biskupa Łozińskiego, w dniu 11 VIII 1925 roku komisja mieszana rządowo-kościelna zaakceptowała powiększenie diecezji. Projekt ten stał się podstawą dla ukonstytuowania terytorium diecezji pińskiej, erygowanej bullą Piusa XI z 28 X 1925 roku, a wprowadzonej w życie 11 grudnia tego roku. W jej skład weszła część diecezji mińskiej, która znalazła się po traktacie ryskim $\mathrm{w}$ granicach państwa polskiego (9 dekanatów - 53 parafie), 6 dekanatów z diecezji wileńskiej oraz 6 parafii - łącznie 67 parafii). Pierwszym biskupem nowej diecezji pińskiej został biskup miński Zygmunt Łoziński. Diecezja weszła w skład metropolii wileńskiej i w 1928 roku obejmowała 17 dekanatów i 172 parafie. Po II wojnie światowej większość terytorium diecezji weszło w skład Białoruskiej SRR. Od 1950 roku terenem diecezji pińskiej pozostającej w granicach PRL zarządzał administrator apostolski rezydujący w Drohiczynie. Ze względu na sytuację polityczną, administratorzy apostolscy używali określenia diecezja w Drohiczynie n. Bugiem. Funkcje administratorów pełnili ks. infułat Michał Krzywicki (1950-1967) i ks. biskup Władysław Jędruszuk (1967-1991), który został pierwszym biskupem drohiczyńskim. W 1991 roku pozostała przy Polsce część utworzyła diecezję drohiczyńską. J. Wiślicki, Konkordat: studium prawne, Lublin 1926, s. 148, art. 9; B. Kumor, Granice metropolii i diecezji polskich (968-1939) cd., „Archiwa Biblioteki i Muzea Kościelne” 22 (1971) s. 335-338.

${ }^{3}$ Parafia rzymskokatolicka pw. Podwyższenia Świętego Krzyża utworzona została w 1412 roku przy drewnianym kościele wybudowanym z fundacji króla Władysława Jagiełły i uposażonym przez księcia litewskiego Witolda. W 1805 roku kościół doszczętnie spłonął. Parafię przeniesiono wów- 
W twierdzy Brześć ${ }^{4}$ funkcjonował także kościół garnizonowy pw. św. Kazimierza Królewicza, ufundowany w XVI wieku. Zabrany w XIX wieku przez prawosławnych, przekształcony został w cerkiew pw. św. Mikołaja. Rewindykowany w 1919 roku przez katolików i w latach 1924-1928 przebudowany według projektu Juliana Lisieckiego, staraniem ks. Antoniego Matejkiewicza (1886-1970), ówczesnego proboszcza parafii wojskowej (od grudnia 1921 roku) i dziekana (do

czas do kościoła pojezuickiego, a od 1808 roku do kościoła bernardynów. Od 1831 roku świątynią parafialną został kościół na przedmieściu, który po pożarze w 1851 roku, staraniem ks. Wincentego Dziemianowicza został gruntownie przebudowany. Murowana świątynia w stylu późnego klasycyzmu przy ul. Unii Lubelskiej została konsekrowana w 1856 roku przez biskupa wileńskiego Wacława Żylińskiego. W bocznym ołtarzu w prawej nawie został umieszczony pochodzący z dawnego kościoła bernardynek w Brześciu XVI-wieczny cudowny obraz Matki Bożej Brzeskiej - MatkiZbawicielki. Obraz ten jest kopią obrazu z rzymskiej bazyliki Matki Bożej Większej, przekazaną kasztelanowi brzeskiemu Adamowi Pociejowi przez papieża Klemensa VIII (1592-1605). Dnia 30 VII 1939 roku bp Kazimierz Bukraba poświęcił kamień węgielny pod przedłużenie tej świątyni, jednak wybuch wojny przerwał budowę na etapie fundamentów. Dnia 15 I 1948 roku kościół został zamknięty przez władze. W 1951 roku budowla została przeznaczona na Muzeum Krajoznawcze, a paramenty kościelne przejął miejski teatr. $Z$ wystroju i wyposażenia wnętrza nic nie ocalało, z wyjątkiem cudownego obrazu, który ukryli wierni. Po 42 latach, dnia 12 VIII 1990 roku została odprawiona po raz pierwszy w tym kościele msza św., a w 1991 roku świątynia została zwrócona katolikom. Jej konsekracji dnia 28 VIII 1992 roku dokonał abp Kazimierz Świątek, który poświęcił także dzwony - „Jan Paweł” i „Zygmunt”. Do świątyni powrócił cudowny wizerunek Matki Bożej, który dnia 30 VI 1996 roku został ukoronowany papieską koroną jako wypełnienie bulli Jana Pawła II z dnia 5 VII 1995 roku. Na murach zewnętrznych świątyni znajdują się epitafia rodziny Jankowskich, która zginęła w wyniku działań wojennych w latach 1915-1920. Wewnątrz świątyni umieszczono w 1993 roku tablicę pamiątkową na cześć obrońców twierdzy brzeskiej z 1939 roku. Por. ADD, Zespół: Archiwum Parafii Brześć, Sygn. XI/Mon, Uroczystość koronacji koronami papieskimi cudownego obrazu Matki Bożej Brzeskiej 30 VI 1996 r., w: Parafia Podwyższenia św. Krzyża, 224005 Brześć - Białoruś (mps - historia parafii i program uroczystości); G. Rąkowski, Ilustrowany przewodnik po zabytkach kultury na Biatorusi, Warszawa 1997, s. 26; Spis kościołów i duchowieństwa diecezji pińskiej w R. P. 1939, Pińsk 1939, s. 65.

${ }^{4} \mathrm{~W} 1830$ roku car Mikołaj I wydał rozkaz zburzenia miasta i wybudowania na jego obszarze Twierdzy Brzeskiej. Powstała ona na początku lat 40-tych XIX stulecia na czterech wyspach, miasto zaś w 1842 roku zostało przeniesione o trzy kilometry na wschód. W ten sposób powstał zespół fortyfikacji wzniesionych według projektu generałów Maleckiego i Karla Oppermana oraz płk. Feldmana, na miejscu dawnego zamku i centrum Brześcia przy ujściu do Bugu rzeki Muchawiec. Twierdza składała się z czterech głównych umocnień obwiedzionych fosami i wałami. Rozbudowę twierdzy rozpoczęto w 1864 roku, a w latach 1878-1879 wybudowano 9 fortów zewnętrznych, tworzących linię obronną o długości 30 kilometrów. Dalszą rozbudowę prowadzono w latach 19111914. Wybudowano wówczas drugą linię 14 fortów, oddalonych o 6-7 kilometrów od twierdzy, tworzących obwód długości 45 kilometrów. Twierdza nie odegrała znaczącej roli podczas I wojny światowej i została bez walki opuszczona przez Rosjan. Na początku II wojny światowej poważnie zniszczona w wyniku zaciętych walk polsko-niemieckich o Brześć w dniach 14-17 IX 1939 roku oraz podczas trwającej ponad miesiąc obrony garnizonu sowieckiego po wybuchu wojny niemiecko-sowieckiej (czerwiec-lipiec 1941). W okresie pierwszej okupacji sowieckiej twierdza służyła jako katownia, gdzie mordowano Polaków i stanowiła punkt etapowy dla więźniów przeznaczonych do deportacji. Por. Twierdza Brześć, s. 25-86; Rąkowski, Ilustrowany przewodnik po zabytkach kultury na Biatorusi, s. 27-30. 
1930 roku). Po utworzeniu Okręgu Korpusu nr IX i mianowaniu ks. A. Matejkiewicza odpowiedzialnym za duszpasterstwo wojskowe w Brześciu, dzięki jego staraniom oraz ofiarności żołnierskiej cerkiew została oddana do użytku katolikom. Przy tej okazji powrócono do pierwotnego wezwania kościoła św. Kazimierza. Ozdobę świątyni stanowiły dwa freski - pierwszy poświęcony bitwie pod Grunwaldem, a drugi Cudowi nad Wisłą. Na drugim fresku ukazany był Józef Piłsudski wydający rozkazy swoim dowódcom, a pośrodku Bogurodzica otoczona księżmi i rannymi żołnierzami i błogosławiąca Polaków w słusznej sprawie. Obok kościoła mieściła się plebania ${ }^{5}$.

Na początku stycznia 1932 roku erygowana została w Brześciu na Przedmieściu Grajewskim (tzw. Grajewka) druga parafia - Najświętszego Serca Pana Jezusa. W wydzierżawionym budynku kolejowym przy ul. Mieszczańskiej staraniem proboszcza, ks. Józefa Moniuszki ${ }^{6}$, powstał kościół parafialny, poświęcony w 1932 roku? $^{7}$.

W latach międzywojennych drugie pod względem wielkości w Brześciu Przedmieście Kijowskie, zwane potocznie Kijówką, w ciągu kilku lat podwoiło liczbę mieszkańców, dochodzącą do 8.000 ludzi. Z tej liczby połowę stanowili katolicy. Uskarżali się oni na znaczną odległość i niełatwą drogę do parafialnego kościoła w śródmieściu. Utrudniały ją tory kolejowe i często zamknięty przejazd, co potwierdzali duszpasterze brzescy $\mathrm{w}$ czasie posługi religijnej $\mathrm{w}$ parafii. W związku z powyższymi odczuwano potrzebę utworzenia kolejnego ośrodka parafialnego na tym przedmieściu, należącym do parafii Podwyższenia Świętego Krzyża. Jej proboszcz i dziekan brzeski ks. Witold Iwicki ${ }^{8}$ w sierpniu 1937 roku

${ }^{5}$ Parafia wojskowa w na terenie twierdzy była jedną z ośmiu parafii w dekanacie brzeskim (Brześć nad Bugiem, Baranowicze, Bielsk Podlaski, Kobryń, Pińsk, Prużana, Siedlce, Słonim) i siedzibą dziekana na terenie IX Poleskiego Dowództwa Okręgu Korpusu, utworzonego dnia 1 VIII 1921 roku. Obecnie dawny kościół św. Kazimierza znajduje się w rękach prawosławnych. Por. Bieszanow, Twierdza Brzeska, s. 120; J. Odziemski, Stużba duszpasterska Wojska Polskiego, Warszawa 1998, s. 72-79.

${ }^{6}$ Moniuszko Józef - kapłan diecezji pińskiej, doktor filozofii. Urodzony w 1887 roku, wyświęcony w 1913, pełnił obowiązki pierwszego proboszcza parafii Najświętszego Serca Pana Jezusa w Brześciu, od 1938 roku był prefektem gimnazjum kupieckiego i kapelanem szpitala powiatowego. Por. Spis kościołów i duchowieństwa diecezji pińskiej w R. P. 1939, Pińsk 1939, s. 18, 40.

${ }^{7}$ Spis kościołów i duchowieństwa diecezji pińskiej w R. P. 1933 i 1934, Pińsk 1933, s. 73.

${ }^{8}$ Iwicki Witold - kapłan archidiecezji mohylowskiej, później diecezji mińskiej (po jej reaktywowaniu w 1917 r.), a od 1926 roku nowo utworzonej diecezji pińskiej, prałat Kapituły Katedralnej Pińskiej. Urodził się 10 V 1884 roku w Wilnie. Tam ukończył gimnazjum i w 1902 roku rozpoczął studia w Akademii Duchownej w Petersburgu, którą ukończył, uzyskując stopień magistra prawa kanonicznego. Święcenia kapłańskie przyjął w 1907 roku. Pracował jako wikariusz w parafii Mozyrz i katecheta w miejscowym progimnazjum oraz prywatnym gimnazjum dla dziewcząt. Pozbawiony przez gubernatora mińskiego na 3 lata pracy kapłańskiej w diecezji mińskiej, w latach 19141915 studiował na Gregorianum w Rzymie, gdzie uzyskał doktorat z prawa kanonicznego. Po powrocie w 1915 roku do Petersburga pracował jako wikariusz metropolitalnego kościoła i parafii pro-katedralnej pw. Wniebowzięcia NMP i prefekt szkół polskich. Od kwietnia 1917 roku podjął obowiązki proboszcza kościoła św. Stanisława BM przy ul. Targowej. Od listopada 1918 roku do lutego 1920 roku brał udział w zebraniach duchowieństwa, zwoływanych przez arcybiskupa Edwar- 
przedstawił ks. Wacławowi Piątkowskiemu , prefektowi szkół w Brześciu, zamysł ordynariusza pińskiego, bpa Kazimierza Bukraby, utworzenia trzeciej parafii w mieście, ze wskazaniem jej lokalizacji na Przedmieściu Kijowskim. W związku z tym 31 sierpnia tego roku ks. Piątkowski zamieszkał prywatnie na Kijówce w dzielnicy Brześć II, przy ul. Gen. Szeptyckiego 7, obok boiska sportowego. Na Przedmieściu Kijowskim w domu kolejowym mieściła się niewielka kapliczka, w której ks. Piątkowski rozpoczął odprawianie codziennej Mszy św., a w ciągu dnia pełnił dotychczasowe obowiązki katechety szkolnego w szkole powszechnej przy ul. Jasnej na Kijówce, w gimnazjum kupieckim i w gimnazjum rzemieślniczym w śródmieściu.

da Roppa, a następnie arcybiskupa Jana Cieplaka, na których dyskutowano o sytuacji Kościoła katolickiego w Rosji po rewolucji bolszewickiej. W 1919 roku ks. Iwicki został aresztowany przez bolszewików i więziony w Moskwie. Zwolniony, przybył w 1921 roku do Polski. W 1924 roku mianowany został rektorem Mińskiego Seminarium Duchownego w Nowogródku, a w 1925 roku rektorem tegoż seminarium w Pińsku. Był również wykładowcą teologii pastoralnej i socjologii. W latach 1927-1932 sprawował urząd wikariusza generalnego. Po śmierci biskupa pińskiego Zygmunta Łozińskiego († 26 III 1932) do 28 VIII 1932 roku był wikariuszem kapitulnym diecezji pińskiej, a od 28 VIII 1932 do 15 VIII 1933 roku pełnił funkcję wikariusza generalnego. W sierpniu 1933 roku został proboszczem parafii Podwyższenia Świętego Krzyża w Brześciu i dziekanem brzeskim. Lata okupacji sowieckiej i niemieckiej przeżywał w bardzo trudnych warunkach. Po opuszczeniu Pińska przez bpa Karola Niemira w zimie 1941 roku, został wikariuszem generalnym diecezji pińskiej. W czasie II wojny światowej organizował pomoc Żydom i więźniom politycznym. Aresztowany przez Niemców z grupą zakładników, więziony był w więzieniu pińskim. Dnia 22 I 1943 roku 38 zakładników zostało przewiezionych do Janowa Poleskiego i rozstrzelanych w pobliżu cmentarza żydowskiego. Ks. Iwicki nie skorzystał z możliwości uwolnienia. Do końca pełnił posługę kapłańską wobec więźniów. Należy do grupy ponad 100 kapłanów zamordowanych przez Niemców na Białorusi (w tym 52 z diecezji pińskiej). Por. Borowski, Wyższe Seminarium Duchowne Diecezji Pińskiej 1925-1939, Drohiczyn nad Bugiem 2000s. 28-31; L. Mikhailik, Kościót katolicki na Grodzieńszczyźnie 1939-1956, Warszawa 2008, s. 129, 161, 285; Niech świadectwo nie będzie zapomniane. Losy Kościoła katolickiego na Białorusi w latach 1917-1953, red. R. Wierna, Grodno 2000, s. 65-66.

${ }^{9}$ Piątkowski Wacław - kapłan diecezji pińskiej. Urodził się 21 IV 1902 roku w Jasionówce koło Białegostoku. Po maturze w 1926 roku rozpoczął studia w seminarium duchownym w Pińsku. Po dwóch latach studiów filozoficznych został wysłany do Rzymu na studia teologiczne. Studiował teologię moralną na Papieskim Ateneum na Lateranie. Rok przed ukończeniem studiów, podczas pobytu w Pińsku poprosił ordynariusza - bpa Zygmunta Łozińskiego o święcenia kapłańskie, które otrzymał dnia 27 IX 1931 roku. Następnie powrócił do Rzymu, by kontynuować studia, ukończone w 1932 roku tytułem doktora teologii dogmatycznej. Po powrocie do diecezji został mianowany dnia 20 VII 1932 roku wicerektorem seminarium duchownego i kapelanem biskupa Kazimierza Bukraby, zajmując równocześnie inne ważne stanowiska w Kurii Biskupiej: notariusza, notariusza Sądu Biskupiego oraz prefekta szkół. Od 28 IX 1934 roku pracował tymczasowo jako administrator parafii Nowojelnia w dekanacie Nowogródek, a od 6 I 1935 roku przybył do Nowogródka, gdzie został rektorem kościoła filialnego pw. Przemienienia Pańskiego (fara Witoldowa) oraz kapelanem sióstr nazaretanek i prefektem Gimnazjum im. Adama Mickiewicza. Od 2 IX 1935 roku podjął obowiązki nauczyciela religii w szkołach powszechnych w Brześciu. R. Dzwonkowski, Leksykon duchowieństwa polskiego represjonowanego w ZSRR 1939-1988, Lublin 2003, s. 474-478; Spis kościołów i duchowieństwa diecezji pińskiej w R. P. 1933 i 1934, s. 142, 171; w R. P. 1939, 67, 148. 
W odpowiedzi na prośbę ks. Piątkowskiego z dnia 30 VIII 1937 roku ordynariusz piński udzielił pozwolenia na przechowywanie w kaplicy Najświętszego Sakramentu ${ }^{10}$. Na początku października tego roku Kuria Diecezjalna przekazała przyszłej parafii szaty i paramenty liturgiczne: 3 obrusy, 6 korporałów, 12 puryfikaterzy, 3 humerały, 2 alby, 3 paski, 2 komże, 10 ręczników, 2 sukienki dla chłopców, bursę do chorych, ornat biały, czarny i czerwony oraz sukienkę na puszkę. Przekazane paramenty należało wpisać do zapoczątkowanej księgi inwentarzowej na poczet mającej tam powstać parafiii ${ }^{11}$.

Najważniejszymi wyzwaniami, które stanęły przez organizatorem nowej parafii były: powołanie społecznego komitetu budowy, wskazanie lokalizacji przyszłego kościoła oraz pozyskiwanie środków na jego budowę, które szacowano na 100000 złotych $^{12}$.

Na zebraniu mieszkańców Przedmieścia Kijowskiego oraz dzielnic Brześć II, IV i V w dniu 21 XI 1937 roku wybrany został społeczny komitet budowy, który przyjął nazwę: Komitet Budowy Kościoła na Przedmieściu Kijowskim w Brześciu nad Bugiem. Jego siedziba mieściła się przy ulicy Jasnej 3. Na zebraniu tym została sporządzona lista członków komitetu, zarządu i komisji rewizyjnej. Jeszcze tego samego dnia zarząd komitetu skierował do Starostwa Powiatowego w Brześciu pismo dotyczące jego rejestracji ${ }^{13}$.

Tabela 1. Skład personalny społecznego komitetu budowy kościoła z 1937 roku/

Table 1. The personal composition of the social committee of the church construction

\begin{tabular}{|c|c|c|c|c|}
\hline l.p. & $\begin{array}{l}\text { Funkcja/ } \\
\text { Function }\end{array}$ & $\begin{array}{l}\text { Nazwisko/ } \\
\text { Surname }\end{array}$ & $\begin{array}{c}\text { Zajmowane } \\
\text { stanowisko/ } \\
\text { Position held } \\
\end{array}$ & $\begin{array}{l}\text { Adres/ } \\
\text { Address }\end{array}$ \\
\hline 1. & Przewodniczący & $\begin{array}{l}\text { Ks. Piątkowski } \\
\text { Wacław }\end{array}$ & $\begin{array}{l}\text { prefekt szkół } \\
\text { miejskich }\end{array}$ & $\begin{array}{c}\text { Brześćc, } \\
\text { ul. Szeptyckiego } 7\end{array}$ \\
\hline \multirow[b]{2}{*}{2.} & \multirow[b]{2}{*}{ Wiceprzewodniczący } & Wójcik Marian & prezydent miasta & $\begin{array}{c}\text { Brześć, } \\
\text { ul. Kilińskiego } 3\end{array}$ \\
\hline & & $\begin{array}{l}\text { Kamiński } \\
\text { Szymon }\end{array}$ & $\begin{array}{l}\text { kierownik Publicznej } \\
\text { Szkoły Powszechnej } \\
\text { nr } 5\end{array}$ & $\begin{array}{l}\text { Brześć, } \\
\text { ul. Browarowa } 4\end{array}$ \\
\hline 3. & Sekretarz & $\begin{array}{c}\text { Maciejczyk } \\
\text { Zygmunt }\end{array}$ & $\begin{array}{l}\text { urzędnik Oddziału } \\
\text { Drogowego PKP }\end{array}$ & $\begin{array}{l}\text { Brześć IV - dom } \\
\text { kolejowy nr } 22\end{array}$ \\
\hline 4. & Skarbnik & Plisko Jan & $\begin{array}{l}\text { urzędnik warsztatów } \\
\text { sygnałowych } \\
\text { w Brześciu }\end{array}$ & $\begin{array}{l}\text { Brześć V - dom } \\
\text { kolejowy nr } 37\end{array}$ \\
\hline
\end{tabular}

${ }^{10}$ ADD, Sygn. VI/K, Lecturis ordynariusza pińskiego bpa Kazimierza Bukraby z 3 X 1937 roku (Num. 3447/37). Podpisani bp Karol Niemira i kanclerz.

${ }^{11}$ ADD, Sygn. VI/K, Kierownik Wydziału Gospodarczego Kurii Diecezjalnej Pińskiej ks. Lucjan Chwiećko do ks. W. Piątkowskiego, pismo z 1 X 1937 roku, datowane w Pińsku (L. 4423/37).

${ }^{12}$ Jeszcze o budowie kościoła na Kijowskim Przedmieściu, „Dziennik Brzeski”, 6 II 1938.

${ }^{13}$ ADD, Sygn. VI/K, Podanie Komitetu Budowy do Starosty Powiatowego w Brześciu z 21 XI 1937 roku - Brześć. 


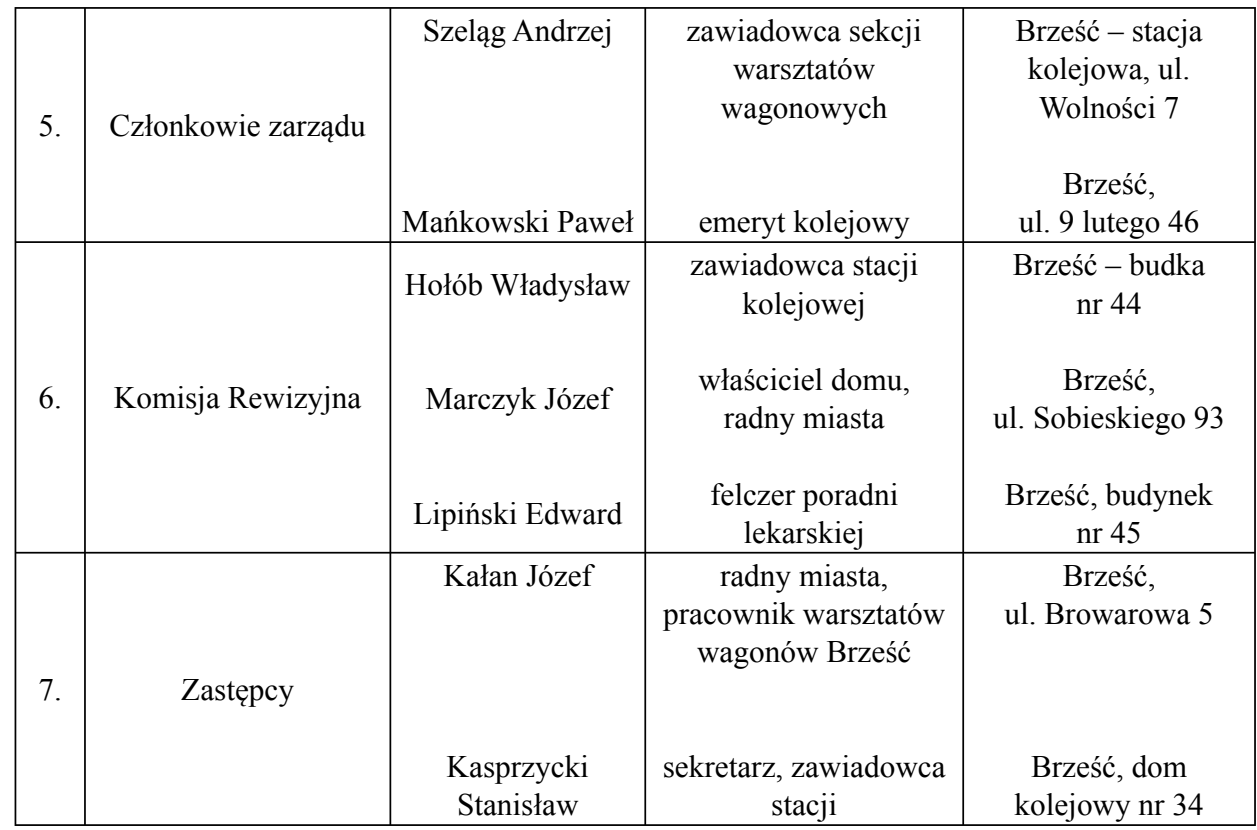

Źródło: ADD, Sygn. VI/K, Zespół Archiwum Parafii Brześć, Skład zarządu Komitetu z 21 XI 1937 r.

Pierwszorzędnym zadaniem społecznego Komitetu Budowy Kościoła było opracowanie projektu świątyni, nabycie placu pod budowę oraz troska o pozyskiwanie funduszy na ten cel. Patronat nad budową kościoła objęli: wojewoda poleski w latach 1932-1939 Wacław Kostek-Biernacki, dowódca Brzeskiego Okręgu Korpusu nr IX generał brygady Czesław (Mikołaj) Jarnuszkiewicz i dyrektor kolei z Wilna, inżynier, ppłk. dyplomowany WP Jan Głazek (Gozek) ${ }^{14}$.

Biorąc pod uwagę opinie mieszkańców Kijówki i większości członków Komitetu, zdecydowano o lokalizacji przyszłego kościoła na terenie nieco wzniesionym, przy ul. Polnej, w sąsiedztwie szkoły. Tam też rozpoczęto gromadzenie materiałów budowlanych ${ }^{15}$. Starania o nabycie tego gruntu nie powiodły się ze względu na bardzo wysoką cenę przedstawioną przez prawosławnych właścicieli. W związku z powyższym wstrzymano dalsze gromadzenie materiałów budowlanych i zaczęto poszukiwania miejsca pod lokalizaję przyszłego kościoła w innej części Kijowskiego Przedmieścia, w pobliżu Szkoły Powszechnej nr 5. W tej sytuacji zarząd Komitetu zwrócił się dnia 12 XII 1937 roku do ordynariusza pińskiego z prośbą o przyznanie pod budowę kościoła obiecanego wcześniej placu (około 2 hektary) na terenach beneficjalnych dwóch parafii brzeskich, obejmujących powierzchnię 35 hektarów. Prośba Komitetu uzyskała aprobatę Rady Dekanalnej

${ }^{14}$ Nowy kościól stanie w Brześciu. Specjalny komitet zajmie się opracowaniem projektu, „Expres Ilustrowany", 21 XII 1937 rok.

${ }^{15}$ Na budowę zdołano już zakupić wagon wapna. Nowy kościół w Brześciu, „Gazeta Poleska”, 2 I 1938 rok. 
Brzeskiej i Diecezjalnej Rady Gospodarczej w Kurii Biskupiej Pińskiej oraz zatwierdzenie biskupa ordynariusza. Przydzielony teren o powierzchni 2,24 hektara przy ul. Jasnej oddalony był o 300 metrów od pierwotnie planowanego. Położony był pomiędzy szosą stanowiącą przedłużenie ulicy Harcerskiej od zachodu i posesją Cyryla Puzika od wschodu, granicząc od południa i północy z gruntami kościelnymi parafii brzeskich. Zaplanowana świątynia miała być murowana i okazała. W planach przyszłej parafii uwzględniono budynki parafialne i gospodarcze, a mianowicie: kaplicę (późniejszy dom katolicki), tymczasową plebanię (w przyszłości jako organistówkę), stróżówkę-organistówkę, studnię, chlew, ogród warzywno-owocowy i ostatecznie plebanię murowaną. Ze względu na tak poważną inwestycję, pociągającą za sobą wysokie koszty realizacji i długotrwałość budowy, na początek zdecydowano się na wybudowanie tymczasowej kaplicy, którą w dalszej przyszłości miała zastąpić okazała świątynia miejska ${ }^{16}$.

O podejmowanych inicjatywach władz kościelnych, miejskich i tamtejszych wiernych katolików na temat organizowania nowego ośrodka parafialnego na Kijówce informowała prasa lokalna: „Dziennik Brzeski”" „Gazeta Poleska”18. Sposób zdobycia funduszy był powszechnie znany. Komitet kierował odezwy do społeczeństwa miasta, nawołując do składania ofiar. Postarał się też o własną pieczęć, księgę protokołów i księgę kasową, kwitariusze i cegiełki w formie bloczków po 50 sztuk opiewające na 20 groszy, 50 groszy i 1 złoty. Każda ofiara była potwierdzona bądź to kwitem, bądź cegiełką. Ponadto używano wszelkich godziwych sposobów zdobywania funduszy, jak: składki, zbiórki, kwesty i imprezy. Planowano również rozsyłać listy ofiar i kwestarzy. Opatrzone odpowiednim wstępem trafiły one np. do urzędu wojewódzkiego miasta Brześcia. Wydrukowano także pocztówki treści religijnej (50 groszy i 1 złoty) z adnotacją na odwrocie: „Dochód ze sprzedaży na budowę kościoła na Kijowskim Przedmieściu w Brześciu nad Bugiem". Najwięcej jednak składali wierni na tacę w czasie nabożeństw kościelnych i do skarbonki ${ }^{19}$.

Po Bożym Narodzeniu 1937 roku ksiądz prefekt Piątkowski rozpoczął odwiedziny rodzin katolickich Kijówki i okolicy, w przewidzianych granicach przyszłej parafii. Była to prawdziwa kolęda. Kapłan święcił domy, badał stan moralny

${ }^{16}$ ADD, Sygn. VI/K, Komitet Budowy do bpa ordynariusza w Pińsku z 12 XII 1937, kolejne pismo z grudnia 1937 roku (brak dokładnej daty); Kierownik Wydziału Gospodarczego Kurii Diecezjalnej ks. Lucjan Chwiećko do ks. W. Piątkowskiego, pismo z 14 III 1938 (L. 1063/38), Kuria Diecezjalna Pińska do przewodniczącego Komitetu ks. Piątkowskiego, pismo z dnia 14 IV 1938 roku,

Pińsk

(L. 1195/38), podpisany sufragan piński, wikariusz generalny bp Karol Niemira.

17 „Dziennik Brzeski” - dziennik ukazujący się od 1936 roku w Brześciu, adres redakcji: ul. Steckiewicza 30.

${ }^{18}$ „Gazeta Poleska” - tygodnik ukazujący się od 1925 roku w Brześciu, którego redakcja mieściła się przy ulicy Piłsudskiego 18. Pismo należało do prasy ogólnoinformacyjnej (obok tygodników „Głos Poleski” i „Polesie”), która stanowiła największą grupę wśród lokalnych pism prasowych. Poza wydarzeniami politycznymi, informowała czytelników o bieżących wydarzeniach społecznokulturalnych w kraju i zagranicą.

${ }^{19}$ Jeszcze o budowie kościoła na Kijowskim Przedmieściu, „Dziennik Brzeski”, 6 II 1938 ro$\mathrm{ku}$. 
mieszkańców, zachęcał do dobrego. Na pamiątkę wizyty duszpasterskiej zamiast obrazków pozostawiał kartki z wierszykiem zachęcającym do święcenia dnia świątecznego:

„Każdy katolik w niedziele i święta

O Mszy, kazaniu sumiennie pamięta,

Nic nie kupuje, nic nie sprzedaje,

Sam nie zarabia, zarobku nie daje!"

Za wszelkie ofiary składane z okazji kolędy darczyńcy otrzymywali podziękowanie. W tej atmosferze sprawa organizowania nowej parafii rozwijała się i nabierała tempa. Najważniejsze, że fundusze rosły, a skarbnik Komitetu Jan Plisko wszystko skrupulatnie zapisywał w księdze kasowej.

Na przeprowadzenie każdorazowej zbiórki publicznej na terenie miasta, powiatu czy województwa poleskiego, z wyjątkiem strefy nadgranicznej, konieczne było uzyskanie stosownego zezwolenia Urzędu Wojewódzkiego Poleskiego - Wydział Społeczno-Polityczny, o które starał się zarząd Komitetu. Takie zezwolenie na przeprowadzenie pierwszej zbiórki w dniu 1 IV 1938 roku otrzymano pod następującymi warunkami: 1 . Zbiórka ma być przeprowadzona jedynie przez osoby imiennie do tego zaproszone; 2 . Osoby przeprowadzające zbiórkę za swe czynności nie mogą pobierać wynagrodzenia; 3 . Osoby przeprowadzające zbiórkę winny być zaopatrzone w legitymacje, odpowiadające warunkom par. 13 rozporządzenia z dnia 14 VII 1934 roku (Dz.U. R. P. Nr 69, poz. 638); 4. Zbiórka winna odbywać się na podstawie sprzedaży cegiełek w cenie 20 groszy, 50 groszy i 1 złoty oraz przez rozsyłanie list ofiar. O wynikach zbiórki oraz sposobie zużytkowania zebranych ofiar należało poinformować Urząd Wojewódzki w ciągu miesiąca w szczegółowym sprawozdaniu ${ }^{20}$.

Wiosną 1938 roku rozpoczęto realizację budowy nowego ośrodka parafialnego. $\mathrm{Na}$ początek podjęto budowę drewnianego, dość prymitywnego domku z przeznaczeniem na stróżówkę. Mieścił się w nim pokój z kuchnią. W ciągu dziesięciu dni budowę stróżówki ukończono. Stróża do dozoru placu budowy na razie nie było. Tymczasem kilka dni później zgłosiło się dwóch mężczyzn poszukujących pracy, proponując wykonanie na miejscu pustaków żwirowych z przeznaczeniem na planowaną budowę kaplicę. Zamieszkali oni w wybudowanym domku. Rozpoczęli pracę od wykopania studni, a następnie przystąpili do produkcji szarych pustaków, układając je na placu. Do koniecznego polewania ich wodą zgłosili się uczniowie, którzy czynili to sprawnie i z radością we wczesnych godzinach rannych, przed zajęciami szkolnymi. Następnie zbudowano szopę na skład materiałów budowlanych. Po wykonaniu potrzebnej liczby pustaków i zakończeniu tej pracy, w stróżówce zamieszkał dozorca wraz z rodziną, w sumie pięć osób ${ }^{21}$.

Równocześnie czyniono starania o uzyskanie zezwolenia na budowę tymcza-

${ }^{20}$ ADD, Sygn. VI/K, Komitet Budowy Kościoła do Starosty Powiatowego Brzeskiego (S. Chmielowskiego) z 22 XII 1937 roku (Dz. Nr 11), Urząd Wojewódzki Poleski do Komitetu Budowy Kościoła z 28 III 1938 roku (Nr B. A. 4), Brześć n. Bugiem.

${ }^{21}$ W. Piątkowski, Kronika Parafii Matki Bożej Królowej Korony Polskiej w Brześciu, s. 2-3 (mps w ADD). 
sowej kaplicy, o które zarząd Komitetu wystąpił dnia 7 IV 1938 roku do Urzędu Wojewódzkiego. Urząd zatwierdził przedstawiony projekt techniczny i udzielił zezwolenia na budowę kaplicy pod następującymi warunkami: 1. Wykonanie tamburu w kancelarii w celu zabezpieczenia od przenikania chłodu; 2. Zapewnienie przewietrzenia kaplicy - w tym celu wszystkie okna, a przede wszystkim górne ich części winny być otwieralne - oraz wykonanie dodatkowych drzwi w miejscu oznaczonym na planie; 4. Pokrycie budynku kaplicy ogniotrwałym dachem ${ }^{22}$. Ponadto Urząd Wojewódzki proponował szczegółowe dopracowanie projektu wysokiego dachu w kościele, zatwierdzonego przez biskupa ordynariusza. Co do usytuowania przyszłego kościoła Urząd Wojewódzki nie zgłaszał zastrzeżeń, a jedynie proponował zwrócenie się do Zarządu Miejskiego celem uzyskania opinii w związku z projektowanymi na planie sytuacyjnym nowymi ulicami, uwzględnieniem ich położenia, kierunku i szerokości, co Zarząd mógł już postanowić $\mathrm{w}$ planie przestrzennym miasta ${ }^{23}$. Uzyskane pozwolenie na budowę kościoła traciło swoją ważność, o ile w ciągu dwóch lat od wydania decyzji prace nie zostaną rozpoczęte lub po ich rozpoczęciu będą zawieszone przez dwa lata. Prace budowlane winny być wykonywane pod nadzorem uprawnionego kierownika technicznego.

Dnia 1 VII 1938 roku rozpoczęto budowę kaplicy, przeznaczoną docelowo na dom parafialny, w którym miał powstać ośrodek kultury i wiedzy religijnej. Wielkość kaplicy opiewała na 15 metrów długości i 9 metrów szerokości. Na zalanych fundamentach ściany wznoszono szybko dzięki rozmiarom wyrobionych pustaków. Po sześciu tygodniach prowadzonych prac budowlanych, dnia 13 sierpnia tego roku kaplica była ukończona. Na jej wieżyczce zawieszono dzwon. Wokół kaplicy postawiono ogrodzenie $\mathrm{z}$ uwzględnieniem większego terenu w wypadku liczniejszej frekwencji wiernych. Jej poświęcenia w niedzielę 14 VIII 1938 roku dokonał ks. Piątkowski, który odprawił też pierwszą Mszę św. na Kijówce. Kazanie na cmentarzu przykościelnym wygłosił ks. Władysław Siekierko ${ }^{24}$, prefekt

${ }^{22}$ Pozwolenie zostało wydane na podstawie art. 343 pkt „a” $i$ artykułu 384 pkt „a” rozporządzenia Prezydenta Rzeczypospolitej z 16 II 1928 roku (Dz. U. RP Nr 23, poz. 202). Od powyższych warunków przysługiwało zarządowi Komitetu Budowy prawo odwołania do Ministerstwa Spraw Wewnętrznych za pośrednictwem Urzędu Wojewódzkiego Poleskiego w terminie do 14 dni od otrzymania pozwolenia. ADD, Sygn. VI/K, Urząd Wojewódzki Poleski - Wydział KomunikacyjnoBudowlany do zarządu Komitetu z 14 IV 1938 roku (Nr KB-3/a), podpisany za wojewodę naczelnik Wydziału inż. T. Sokołowski.

${ }^{23}$ ADD, Sygn. VI/K, Urząd Wojewódzki Poleski - Wydział Komunikacyjno-Budowlany do Komitetu Budowy z 21 V 1938 roku (Nr KB. 3/k.) podpisany za wojewodę naczelnik Wydziału inż. T. Sokołowski.

${ }^{24}$ Siekierko Władysław - kapłan diecezji pińskiej, kapelan (w stopniu rotmistrza) 27 Pułku Ułanów Nowogródzkiej Brygady Kawalerii (Nieśwież). Urodził się 10 X 1909 roku w Obniżu, gimnazjum ukończył w Drohiczynie nad Bugiem i wstąpił do Wyższego Seminarium Duchownego w Pińsku, święcenia kapłańskie otrzymał 31 III 1934 roku z rąk bpa Kazimierza Bukraby. Pracował w parafiach w Ciechanowcu, Brześciu, Łunińcu (także jako prefekt gimnazjum), Nieświeżu (prefekt Seminarium Nauczycielskiego 1936-1937). Wysłany na studia do Rzymu, zmuszony był przerwać je w 1939 roku z powodu wojny. W czasie okupacji pracował w Jabłonnie (diec. podlaska), Starej Wsi, Ciechanowcu, Winnej i Perlejewie. Był aresztowany przez Niemców. W 1945 roku wstąpił do 
szkół w Brześciu. Dnia poprzedniego ks. Piątkowski przeniósł procesjonalnie do wybudowanej kaplicy obraz Matki Bożej Ostrobramskiej z dotychczasowej kapliczki na terenie dzielnicy Brześć II, gdzie dotychczas odprawiał. Od tego dnia Msze św. odprawiane były na Kijówce codziennie, a w niedziele i święta dwie: o godzinie 9.00 dla młodzieży i 11.00 suma. Do czasu kanonicznej erekcji parafii na Kijówce wierni sakramenty (chrzty, śluby, pogrzeby) przyjmowali w parafii macierzystej ${ }^{25}$.

Dnia 16 IX 1938 roku biskup piński Kazimierz Bukraba wraz z ks. Lucjanem Żołądkowskim ${ }^{26}$, proboszczem i dziekanem brzeskim debatowali na temat granic przyszłej parafii na Kijowskim Przedmieściu. Jej granicę miały wyznaczać: tor kolejowy Brześć-Baranowicze od północy i wschodu, tor kolejowy Brześć-Kowel od zachodu, parafia Zbirohi (Zbirogi) i parafia Małoryta (Zaoście) od południa i północnego wschodu. Do przyszłej parafii pod wezwaniem Matki Boskiej miały należeć następujące osiedla: Przedmieście Kijowskie, Brześć II, Brześć IV, Brześć V, Brzozówka, Czerwony Dwór, Huźnie, Kamienica Żyrowiecka, Kamienna, kolonia Jaz, Kruszyna, Kunachy, folwark Ostrów-Kowalewo, folwark Ostrów, ga-

Zgromadzenia Księży Filipinów w Gostyniu, gdzie pełnił równocześnie funkcję prefekta gimnazjum państwowego. W roku następnym przeniesiony został do Tarnowa dla organizowania studiów seminaryjnych dla filipinów w Polsce. Do 1952 roku pełnił tam funkcję przełożonego, a potem pracował w Czerwińsku. W 1953 roku powrócił do diecezji. Pracował w Ciechanowcu, od 1956 roku był proboszczem w Kleszczelach. Po wybudowaniu kościoła w Czeremsze 1957-1958 został pierwszym proboszczem erygowanej tam parafii. Od 1962 roku był proboszczem w Grodzisku, gdzie ze względu na stan zdrowia przeszedł w lipcu 1966 roku na emeryturę i nadal rezydował w Grodzisku. W 1969 roku przeniósł się do własnego mieszkania w Siemiatyczach. Zmarł na atak serca 24 X 1979 roku, pochowany został na cmentarzu parafialnym w Siemiatyczach. Por. E. Borowski, Noty biograficzne o zmarlych kapłanach diecezji pińskiej, Drohiczyn nad Bugiem 1982, s. 322-323 (mps w ADD).

${ }^{25}$ Piątkowski, Kronika parafii, s. 3.

${ }^{26}$ Żołądkowski Lucjan - kapłan diecezji mińskiej, następnie pińskiej, kanonik honorowy Kapituły Katedralnej Mińskiej. Urodził się 13 VII 1883 roku, święcenia kapłańskie przyjął 25 I 1909 roku w Petersburgu. Od 1910 roku był wikariuszem przy Złotej Górce w Mińsku, od 1911 roku administratorem parafii przy kościele św. Szymona i Heleny w Mińsku, w latach 1923-1933 proboszczem parafii w Baranowiczach i dziekanem baranowickim. Wybudował kościół Podwyższenia Krzyża Świętego (1925) i kościół Matki Bożej Królowej Korony Polskiej w Baranowiczach. W latach 1933-1937 pełnił obowiązki proboszcza parafii Najświętszego Serca Pana Jezusa w Brześciu na Grajewskim Przedmieściu (ul. Mieszczańska) i dziekana brzeskiego oraz rektora kościoła filialnego w Skokach. W latach 1937-1938 piastował urząd dziekana i proboszcza kościoła Podwyższenia Krzyża Świętego w Brześciu nad Bugiem. Od 1938 roku został kierownikiem Wydziału Metrykalnego Kurii Biskupiej w Pińsku. W 1940 roku zastępował przebywającego na leczeniu sanatoryjnym proboszcza z Peliszcz, ks. Wacława Tumiłowicza, i ostatecznie pozostał tam na stałe. Utrzymywał stały kontakt i współpracę z Armią Krajową, działającą na terenie parafii o kryptonimie „Emilia”. Po wojnie pozostał w tej parafii, położonej w dekanacie i obwodzie brzeskim, obsługiwał także parafię kamieniecką. Zmarł na raka dnia 17 VII 1946 roku w Brześciu i pochowany został na cmentarzu katolickim w Brześciu, przy ul. Puszkińskiej (dawniej 3 Maja) przy neoklasycznej kaplicy. Elenchus ecclesiarum et cleri saecularis ac regularis dioecesis minscensis pro Anno Domini 1924, s. 20-21, 47; Borowski, Noty biograficzne o zmartych kapłanach, s. 161; K. Wojciechowski, Cmentarz katolicki w Brześciu, „Niedziela”, nr 45 (737) z 4 XI 2012, s. 7. 
jówka Pożeżyn, folwark Puhaczewo, wieś Puhaczewo, Podlesie, chutory Romanowskie, Saki, Salne, Witłowy, Wólka Zastawska, Wólki, Wyczółki, Skoczyki, Tryszyn, kolonia Tryszyn, Zabłocie, Nowe Zadworce (po prawej stronie toru kolejowego Brześć-Baranowicze) oraz Zasłuczno.

Po wizycie duszpasterskiej przeprowadzonej w styczniu 1939 roku i dokładniejszym rozeznaniu terenu parafii ks. Piątkowski proponował Kurii Biskupiej Pińskiej dołączenie do parafii kolejnych osiedli: Literżany, Sienioszany, Wałki, Zahije, Żabiniec. Biorąc pod uwagę rozpoczęcie roku szkolnego i względy gospodarcze przyszły proboszcz w przesłanym piśmie sugerował biskupowi utworzenie nowej parafii na Kijowskim Przedmieściu od dnia 1 X 1939 roku $^{27}$.

Dotychczas ksiądz Piątkowski mieszkał na Kijowskim Przedmieściu już $\mathrm{w}$ trzecim z kolei mieszkaniu, oddalonym o kilometr drogi od kaplicy. Pierwsze z nich znajdowało się na terenie Brześcia II, drugie przy ul. Gen. Szeptyckiego 7, trzecie przy ulicy Zachodniej 12, w domu prywatnym rodziny Ilaponiuk. Gospodyni proboszcza była zaangażowana w pracę Komitetu Budowy, a jej syn był ministrantem. Teraz należało pomyśleć o samodzielnym mieszkaniu dla księdza proboszcza w najbliższym sąsiedztwie tworzącej się parafii. W miesiącach wakacyjnych 1938 roku ks. Piątkowski wyruszył z cieślą w okolice Brześcia w poszukiwaniu drewnianego domu na sprzedaż, który planował przenieść na Kijówkę. Dokonał już niemal transakcji kupna upatrzonego domu, kiedy właściciel sprzedaż odwołał. Ponownie wyruszył ks. Piątkowski wraz z ministrantem w okolice Puszczy Białowieskiej i tam znalazł odpowiedni dom drewniany na plebanię. Uzgodnił jego cenę na 2600 złotych, łącznie z rozebraniem go, przywiezieniem i postawieniem na wskazanej parceli w Brześciu, z czego sprzedawca wywiązał się w terminie. Dnia 22 XI 1938 roku proboszcz zamieszkał w swej plebanii przy ul. Jasnej 29. Ułatwiło to parafianom dostęp do duszpasterza, a jemu pracę pastoralną ${ }^{28}$.

Jeszcze $\mathrm{w}$ trakcie prac przy budowie plebanii ordynariusz piński erygował dnia 16 X 1938 roku parafię Matki Bożej Królowej Korony Polskiej w Brześciu nad Bugiem ${ }^{29}$. Było to ważne wydarzenie dla katolików tego miasta, przyjęte przez nich z radością. Tego dnia na wieczornym nabożeństwie eucharystycznym dziekan brzeski, ks. Lucjan Żołądkowski z Grajewki, odczytał akt erekcyjny biskupa pińskiego i przedstawił osobę ks. Wacława Piątkowskiego jako organizatora parafii i jej proboszcza. Następnie mówił o obowiązkach proboszcza i parafian. Po jego wystąpieniu odśpiewano litanię loretańską do Matki Bożej, dziękczynny hymn „Te Deum laudamus” oraz odprawiono nabożeństwo eucharystyczne z błogosławieństwem Najświętszym Sakramentem. Końcowa pieśń „Boże coś Polskę” zakończyła liturgię tego dnia.

${ }^{27}$ ADD, Sygn. VI/K, ks. Piątkowski do Kurii Diecezjalnej Pińskiej z 22 IX 1938 roku, z późniejszym dopiskiem w styczniu 1939 roku.

${ }^{28}$ Piątkowski, Kronika parafii, s. 5.

${ }^{29}$ Dekret erekcyjny nowej parafii winien był zostać ogłoszony z ambony wiernym w najbliższą niedzielę - 16 października $\mathrm{z}$ wskazaniem jej granic. Od tego dnia wierni zamieszkali na terenie nowo utworzonej parafii w sprawach religijnych mieli zwracać się do swojego proboszcza. ADD, Sygn. VI/K, Kuria Diecezjalna Pińska, Dekret erekcyjny parafii z 8 X 1938 roku (Num. 4111/38).. 
Nowa parafia wydzielona z parafii Podwyższenia Świętego Krzyża objęła część miasta noszącą nazwę Kijowskie Przedmieście oraz szereg osiedli wiejskich. Nie otrzymała ona z macierzystej parafii beneficjum kościelnego na utrzymanie proboszcza i wikariuszy. Dotychczasowe beneficjum kościelne (nieruchomości: miejska i ziemska) parafii Podwyższenia Świętego Krzyża pozostało nie zmienione. Po wysłuchaniu opinii jej proboszcza oraz Kapituły Katedralnej ordynariusz zarządził, iż wymienione nieruchomości będące własnością Kościoła rzymskokatolickiego będą w dalszym ciągu należeć w całości do parafii Podwyższenia Świętego Krzyża, lecz od daty dekretu parafii Matki Boskiej Królowej Korony Polskiej trzecia część dochodu z tego folwarku kościelnego, wchodzącego w skład owych nieruchomości, ma stanowić własność każdorazowego proboszcza parafii MB Królowej Korony Polskiej z kościołem na Kijowskim Przedmieściu i winna być mu wypłacana corocznie przez każdorazowego proboszcza parafii Podwyższenia Świętego Krzyża ${ }^{30}$.

Ostatecznie granice powstałej parafii wyznaczyły tory kolejowe: Brześć Centralny - Kowel i Brześć Centralny - Baranowicze oraz terytorium parafii Zbirogi (Zbirohi) i Małoryta. Do parafii na Kijówce należały miejscowości po prawej i lewej strony obu trakcji kolejowych: Przedmieście Kijowskie, Brześć II, Brześć IV, Brześć V, Brzozówka, Szpanowicze (część), Tryszyn, Kamienica Żyrowiecka, Puhaczewo, Chutory Romanowskie i niewielkie osiedla. Od dnia 16 X 1938 roku wierni zamieszkujący wyżej wymienione miejscowości i dzielnice miasta swoje potrzeby religijne realizowali we własnym kościele parafialnym. Młoda parafia w czasie pierwszych kilku miesięcy otrzymywała z Kurii Diecezjalnej i od prywatnych darczyńców niezbędne szaty i sprzęt liturgiczny, o które zabiegał proboszcz. Kuria Diecezjalna Pińska poleciła ks. kanonikowi Piątkowskiemu sporządzenie inwentarza kościelnego powstałej parafii według nowego wzoru obowiązującego w diecezjii ${ }^{31}$. Ofiarność wiernych, chęć do pracy, gorliwość i pobożność były objawem żywej wiary tamtejszych mieszkańców.

Wkrótce potem proboszcz poważnie zachorował na przewlekłą grypę. Z pewnością było to spowodowane ogólnym osłabieniem organizmu na skutek przepracowania. Rzeczywiście pracy miał niemało. Jako prefekt etatowy uczył religii, prowadząc 24 lekcje tygodniowo. Nadto jego czas pochłaniały nabożeństwa kościelne, chrzty, śluby, pogrzeby, spowiedzi, posługa chorym, egzaminowanie dzieci, prowadzenie organizacji religijnych w parafii, nadzór nad cmentarzem, przygotowania do budowy kościoła oraz kierowanie komitetem budowy. Ponadto sam podejmował niektóre prace fizyczne. Mimo choroby nie poddawał się, nie opuszczając ani jednego dnia Mszy św. Po trzech tygodniach najgorsze minęło i na tydzień przed Bożym Narodzeniem 1938 roku ksiądz proboszcz był już zdrów.

W czasie drugiej kolędy 1938/39 na Kijowskim Przedmieściu wszelkie ofiary,

${ }^{30}$ ADD, Sygn. VI/K, Dekret erekcyjny parafii biskupa Bukraby z 8 X 1938 roku (Num. 4111/38), Biskup Bukraba „do czytających” z 8 X 1938 roku (L. 4139/38).

${ }^{31}$ ADD, Sygn. VI/K, Kuria Diecezjalna Pińska do proboszcza i dziekana w Brześciu oraz do proboszcza ks. Piątkowskiego z 11 X 1938 (L. 4168/38); podpisani - prałat ks. Nikodem Tarasiewicz i kanclerz Kurii ks. Bronisław Kiełbasa do proboszcza, ks. Piątkowskiego, z 11 X 1938 roku (L. 4167/38). 
które z tej okazji ks. Piątkowski przyjmował, przeznaczał na budowę kościoła, dając parafianom odpowiednie pokwitowanie, podobnie jak w roku poprzednim. Wierni przyjmowali go serdecznie. Zgłaszali gotowość pomocy przy budowie i dziękowali mu za dotychczasowe inicjatywy pastoralne. Wszystkie dotychczasowe przedsięwzięcia przy organizacji parafii jednoczyły mieszkańców Kijowskiego Przedmieścia z tymi, którzy tu w ostatnim czasie zamieszkali. Frekwencja w kościele w niedzielę i święta wzrosła przynajmniej dwukrotnie, do tego stopnia, że wybudowana niedawno kaplica nie mieściła wiernych, stąd znaczna ich liczba uczestniczyła w liturgii, pozostając na zewnątrz, najczęściej na cmentarzu.

Wkrótce najważniejszym zadaniem stało się oświetlenie kaplicy. Świece i lampy naftowe były niewygodne, zwłaszcza w godzinach wieczornych. Dyrekcja elektrowni nie wyrażała zgody na doprowadzenie linii elektrycznej do kaplicy na koszt elektrowni ze względu na znaczną odległość od domów mieszkalnych, gdzie taka lina była już doprowadzona. $Z$ pomocą przyszedł mieszkaniec Brześcia, który te koszty poniósł, gdyż jak tłumaczył, parafia jest ośrodkiem społecznokulturalnym i godnym poparcia. Dyrektor szkoły miejscowej i radny miasta Szymon Kamiński wystarał się w Zarządzie Miejskim o doprowadzenie do kaplicy kilkusetmetrowego chodnika od ul. Jasnej, co ułatwiło wiernym dojście do kościoła mimo braku utwardzonej drogi.

Cmentarz grzebalny parafii brzeskich znajdował się na terenie powstałej parafii. Jego administracja spoczęła teraz na ks. Piątkowskim, który umiał okazywać zrozumienie wobec wygórowanych żądań rodzin zmarłych. Na co dzień cmentarza doglądał stróż, który mieszkał tam w domu kościelnym.

W Wielkim Poście 1939 roku odprawiono w parafii pierwsze rekolekcje. Frekwencja była wysoka. Ponad 2.000 wiernych (oprócz młodzieży szkolnej) wysłuchało rekolekcyjnych nauk stanowych i przyjęło Komunię Świętą. Triduum Paschalne odprawiono $\mathrm{w}$ godzinach porannych, a kościół pozostawał otwarty przez całą dobę, $\mathrm{z}$ możliwością odprawiania adoracji także w godzinach nocnych. W Wielką Sobotę 9 IV 1939 roku ksiądz proboszcz jeździł samochodem użyczonym mu przez dowódcę oddziału pancernego stacjonującego w twierdzy brzeskiej, by w odległych miejscowościach poświęcić pokarmy i domy. W Wielkim Tygodniu ksiądz proboszcz wraz z uczniami szkolnymi posadził na placu przykościelnym 50 drzewek owocowych: jabłoni, grusz i wiśni. Drzewka pochodziły ze szkółki kolejowej z dzielnicy Brześć II, przekazane nieodpłatnie parafii przez Zarząd Kolei. Było to niejako oczywiste, gdyż na kolei pracowała większość parafian. Po Wielkanocy ksiądz proboszcz posadził krzewy owocowe: agrest, porzeczki i maliny, zagospodarowując w ten sposób grunty należące do parafiii ${ }^{32}$.

Po Świętach Wielkanocnych 1939 roku dobudowano przy kaplicy zakrystię przylegającą do jej bocznych drzwi. Następnym etapem pracy było sporządzenie planu przyszłego kościoła.

Pierwszy projekt przedstawił ks. Piątkowskiemu inż. Barański, wykładowca w szkole technicznej w Brześciu. Jednak projekt ten nie uzyskał pozytywnej oceny wszystkich zainteresowanych. Bryła świątyni była za duża, budowla przypo-

\footnotetext{
${ }^{32}$ Piątkowski, Kronika parafii, s. 6.
} 
minała lokomotywę, co większości parafian nie odpowiadało. Parafianie polecili mu inżyniera, Włocha, który wkrótce przedstawił gotowy projekt kościoła o trzech nawach z kaplicą boczną i zakrystią. Ten projekt zdaniem proboszcza był do przyjęcia. Natomiast wygląd zewnętrzny bryły kościoła na załączonej fotografii nie odpowiadał mu. Wyglądał na zbyt masywny, a jego mury na nadmiernie grube.

Na początku marca 1938 roku zgłosił Komitetowi Budowy swe usługi architektoniczne Wincenty Henryk Wdowiszewski, inżynier bez dyplomu, a może nawet technik, pracownik Urzędu Wojewódzkiego, zamieszkały w Brześciu przy ul. Ogrodowej 4. Według jego planów zbudowano już dwa niewielkie kościoły, m.in. w Peliszczach w powiecie brzeskim. Właśnie on został wybrany do wykonania projektu budowy kościoła na Kijówce.

Stosowna umowa $\mathrm{w}$ przedmiocie sporządzenia projektu budowy kościoła między zarządem Komitetu Budowy a architektem Wdowiszewskim została zawarta. Zawierała ona wykonanie: 1. Szkicu wstępnego w podziałce 1:200 wraz z perspektywicznym widokiem całości gmachu w podziałce 1:100;2. Wykonanie projektu szczegółowego w podziałce 1:100 wraz ze statycznymi obliczeniami i kosztorysem; 3. Wykonanie rysunków roboczych do budowy w podziałkach właściwych potrzebnych do realizacji (od 1:100 do 1:1), rysunków ogólnych (rzuty, przekroje,lica) i rysunków szczegółowych drzwi, okien, słupów, wykończenia tynków, ołtarzy, ambony. Architekt zobowiązał się wykonać powyższe prace we właściwym ujęciu konstrukcyjnym i architektonicznym, aby projekty mogły być zatwierdzone przez władze kościelne i administracyjne. Autor projektu był zobowiązany do nieodpłatnego wykonania koniecznych poprawek i uzupełnień w planie przed jego zatwierdzeniem. Natomiast za dodatkowe poprawki po zatwierdzeniu projektu należało dodatkowo zapłacić. Komitet przeznaczył dla architekta kwotę 2.000 złotych tytułem kosztów własnych jakie miał on ponieść przy sporządzaniu elaboratów technicznych oraz w czasie budowy kościoła, którą przewidywano zakończyć przed 1940 rokiem $^{33}$. Termin wykonania projektów został wyznaczony na dzień $10 \mathrm{~V} 1938$ roku. Ewentualne spory, które nie mogłyby być załatwione w drodze polubownej, miał rozstrzygać Sąd Okręgowy w Pińsku.

Już w marcu 1938 roku Wdowiszewski przedstawił gotowy szkic projektu kościoła. Wspólne oględziny na miejscu placu budowy dokonane przez architekta i proboszcza trwały długo. Wyjaśniano wówczas wszelkie wątpliwości i pytania, a podanie do Urzędu Wojewódzkiego z prośbą o przejrzenie, sprawdzenie, zatwierdzenie i wydanie pozwolenia na budowę uzyskało pozytywną akceptację Urzędu. W maju tego roku Urząd Wojewódzki odesłał parafii zatwierdzony plan z zezwoleniem na budowę. Kierownictwo budowy przejął urzędnik wojewódzki,

${ }^{33}$ Należność płatności została wyszczególniona w ratach: kwota 200 złotych po wykonaniu szkiców wstępnych do zatwierdzenia, 300 złotych po wykonaniu rysunków projektu kościoła bez obliczeń statycznych, 800 złotych po wykonaniu całkowitego projektu budowy wraz z obliczeniami i kosztorysem do zatwierdzenia, 700 złotych w ratach w miarę postępu budowy tytułem zwrotu za wykonanie rysunków roboczych. Por. ADD, S. VI/K, Umowa spisana pomiędzy przedstawicielami Komitetu Budowy a architektem Wincentym H. Wdowiszewskim (brak daty); Oświadczenie autora projektu Wdowiszewskiego na ręce ks. Piątkowskiego na temat uzupełnień i zmian w projekcie z 4 VII 1938 roku, Brześć nad Bugiem. 
inż. Kozłowski. Najogólniej plan zakładał wykonanie fundamentu z kamienia i betonu, ścian z cegły, wiązania dachu, drzwi i okien z drzewa.

Z przedstawionych dnia 19 III 1938 roku Kurii Biskupiej trzech szkiców projektu kościoła kierownik Wydziału Gospodarczego Kurii ks. Ludwik Chwiećko ${ }^{34}$ przesłał dnia 21 III 1938 roku ks. Piątkowskiemu informację, że biskup ordynariusz wybrał trzeci szkic projektu, oznaczony jako „odmiana 2 " i pragnie, aby według niego zostały sporządzone plany budowy. W zatwierdzonym przez Kurię Biskupią szkicu ks. Piątkowski dwukrotnie zalecał architektowi dokonanie zmian, a mianowicie: zwiększenie długości i szerokości budowli (z 16 na 24 metry), uwzględnienie przejścia z kaplicy do nawy bocznej, co spowodowało wydłużenie korytarza przed kaplicą. Ponadto został wydłużony hełm wieży. Po dokonaniu zmian architekt polecił księdzu Piątkowskiemu zatwierdzenie w Kurii Biskupiej i Urzędzie Wojewódzkim poczynionych zmian celem uniknięcia mogących powstać trudności i nieporozumień. Ostateczny projekt budowy kościoła uzyskał zatwierdzenie Diecezjalnej Rady Gospodarczej i biskupa. Jego opis oraz obliczenia statytyczne sporządzone w dwóch egzemplarzach zostały dnia 14 VII 1938 roku przesłane prezesowi Komitetu Budowy Kościoła, ks. Piątkowskiemu ${ }^{35}$.

W grudniu 1938 roku architekt Wodziszewski przedstawił dwa warianty projektu kościoła z dokładnym opisem wnętrza, które zostały przesłane do Rady Gospodarczej Kurii Biskupiej w Pińsku, a już po miesiącu Komitet otrzymał ostateczne ich zatwierdzenie. Wykonawca projektu winien był dokładnie uwzględnić, rozrysować i opisać każdy szczegół budowlany. Należało dokonać obliczeń ob-

\footnotetext{
${ }^{34}$ Chwiećko Lucjan - prałat papieski, kanonik Kapituły Katedralnej Pińskiej i kanonik honorowy Mohylewskiej Kapituły Katedralnej. Urodził się 22 XI 1889 roku. Po ukończeniu szkoły podstawowej w Dąbrowie uczył się w szkole średniej w Sokółce, a następnie odbył praktykę na pomocnika aptekarskiego w Grodnie. Po Seminarium Duchownym w Petersburgu otrzymał święcenia kapłańskie w 1914 roku i dyplom magistra teologii. W latach 1915-1918 był profesorem seminarium w Petersburgu, następnie proboszczem prokatedry w Petersburgu w latach 1919-1923. Wspólnie z ks. Fabianem Abrantowiczem założył Białoruskie Zjednoczenie Chrześcijańsko-Demokratycznego (chadecja). Aresztowany przez bolszewików, przebywał z arcybiskupem Janem Cieplakiem w więzieniu w Moskwie od 14 VIII 1923 do 13 II 1925 roku i stanął przed sądem w tzw. procesie 14 z wyrokiem 10 lat więzienia. Drogą wymiany więźniów został zwolniony i podjął pracę w Szymanowie k. Warszawy. W latach 1926-1931 był rektorem Instytutu Misyjnego w Lublinie. W 1932 roku został mianowany proboszczem parafii Szczytniki w dekanacie brzeskim oraz wykładowcą teologii pastoralnej i języka białoruskiego w Seminarium Duchownym w Pińsku. Zajmował różne stanowiska w kurii pińskiej. W czasie II wojny pracował jako proboszcz parafii Chotów w dekanacie stołpeckim. Aresztowany przez gestapo w 1944 roku, był więziony w Stołpcach, a w czasie przesłuchań wielokrotnie ciężko pobity. Zmarł w maju 1944 roku w szpitalu w Stołpcach na skutek odniesionych obrażeń. Zawsze podkreślał swoją białoruską narodowość. Por. Borowski, Wyższe Seminarium Duchowne Diecezji Pińskiej, s. 81-82; T. Madała, Polscy księża katoliccy w więzieniach i łagrach sowieckich od 1918 r., Lublin 1996, s. 37; Mikhailik, Kościót katolicki na Grodzieńszczyźnie, s. 161, 285.

${ }^{35}$ ADD, Sygn. VI/K, Kuria Diecezjalna w Pińsku do ks. W. Piątkowskiego z 21 III 1938 roku, Pińsk (L.dz. 12038/38), podpisany ks. L. Chwiećko; Architekt do ks. Piątkowskiego w Brześciu (ul. Szeptyckiego 7) z 7 IV 1938 roku, Brześć; Kierownik Wydziału Gospodarczego Kurii, ks. Chwiećko do prezesa Komitetu ks. Piątkowskiego z 14 VII 1938 roku (L. 2451/38), Pińsk.
} 
ciążenia poszczególnych elementów budowy, czyli obliczeń statycznych. W oczekiwaniu na gotowy plan kościoła ks. proboszcz przeprowadził nieprzyjemną rozmowę telefoniczną z inż. Barańskim, którzy krytykował powierzenie architektowi Wdowiszewskiemu sporządzenie planu przyszłego kościoła na Kijówce. W odpowiedzi ksiądz Piątkowski odparł, iż nikt z zainteresowanych inżynierów nie przedstawił gotowego planu, Wdowiszewski zaś już w marcu 1938 roku przekazał dwa gotowe szkice z koniecznymi obliczeniami i wykresami, a jeden z nich uzyskał zatwierdzenie księdza biskupa. Rozmówca domagał się od proboszcza wycofania planu architekta Wdowiszewskiego, co jednak nie nastąpiło.

W 1938 roku do pracy w parafii na Kijówce, po trzech latach pracy kapłańskiej, przybył ks. Antoni Grzybowski ${ }^{36}$. Podjął on obowiązki wikariusza parafialnego i prefekta w szkole technicznej. Na co dzień był prawą ręką proboszcza. $\mathrm{Z}$ powodu odczuwalnego chłodu na nowej plebanii, zamieszkał prywatnie w domu Pawła Mańkowskiego przy ulicy 9 lutego nr 46, członka zarządu Komitetu Budowy $^{37}$. W parafii pracował jedynie przez rok. W dniu IX 1939 roku zastapił go ks. Wacław Chojecki ${ }^{38}$ jako mansjonarz przy kościele na Kijówce ${ }^{39}$. Ponadto dziekan brzeski delegował dnia 2 X 1939 roku na wikariusza do parafii Matki Bożej Królowej Korony Polskiej ks. Józefa Bartuszka ${ }^{40}$.

Wiosna 1939 roku w parafii Matki Bożej Królowej Korony Polskiej powstał Żywy Różaniec, który liczył 10 kółek-róż. Kółko liczyło 15 osób, odpowiednio

${ }^{36}$ Grzybowski Antoni - kapłan diecezji pińskiej. Urodził się w 1906 roku, święcenia kapłańskie otrzymał w 1935 roku, po święceniach pracował w Brześciu w parafii Podwyższenia Świętego Krzyża i był prefektem szkół średnich. Po wojnie od 1945 roku był proboszczem kościoła Świętej Trójcy w Czernawczycach, który był nieprzerwanie czynny. Tam zmarł 11 X 1988 roku. A. Hlebowicz, Kościół w niewoli, Warszawa 1991, s. 31, 41, 88; Spis kościołów i duchowieństwa diecezji pińskiej w R. P. 1939, s. 66, 147.

${ }^{37}$ Piątkowski, Kronika parafii, s. 6.

${ }^{38}$ ADD, Sygn. VI/K, Kuria Diecezjalna w Pińsku do ks. Piątkowskiego z 28 VII 1939 roku (L. 2550/39) podpisany ks. Chwiećko.

Chojecki Wacław - kapłan diecezji lubelskiej. Urodził się w 1868 roku, święcenia kapłańskie przyjął 28 IX 1890 roku. Do 1926 roku był proboszczem w Czartowcu w dekanacie tyszowieckim, diecezji lubelskiej. Od tego roku pracował na terenie diecezji pińskiej, najpierw jako proboszcz w Horodzieju 1926-1928, potem w Kiwatyczach 1928-1933, a w latach 1934-1935 przebywał na urlopie zdrowotnym. Od 1935 roku pełnił obowiązki proboszcza w Czerwiszczach, w dekanacie janowskim. Po wojnie pracował w parafii Bałandycze. Zmarł w 1952 roku. Borowski, Noty biograficzne o zmartych kapłanach, s. 194.

${ }^{39}$ ADD, Sygn. VI/K, Kuria Diecezjalna Pińska do proboszcza parafii ks. Piątkowskiego z 28 VII 1939 (L. 2550/39), podpisany ks. kanonik Chwiećko.

${ }^{40}$ ADD, Sygn. VI/K, Proboszcz i dziekan brzeski do ks. Piątkowskiego z 2 X 1939 roku (L. 70/d). Bartuszek Józef - kapłan diecezji pińskiej. Urodził się w 1908 roku, wyświęcony na kapłana w 1936 roku. Jako neoprezbiter pełnił obowiązki wikariusza w Wysokim Litewskim, w dekanacie brzeskim, a także prefekta szkół powszechnych. Podczas II wojny światowej był proboszczem w Zaostrowieczach (dek. nieświeski). Aresztowany przez Niemców 28 VI 1942 roku, był więziony w Baranowiczach. Rozstrzelany 13 VII 1942 roku w obozie Kołdyszewo koło Baranowicz na cmentarzu prawosławnym (lub w 1943 roku w Baranowiczach). E. Borowski, Wyższe Seminarium Duchowne Diecezji Pińskiej 1925-1939, Drohiczyn nad Bugiem 2000, s. 133-134; Niech świadectwo nie będzie zapomniane, s. 60. 
do 15 tajemnic różańca. Kolejną organizacją parafialną była Straż Honorowa Najświętszego Serca Jezusowego - praktyka pobożna oparta na przykładzie adoracji Najświętszego Sakramentu, z tą różnicą, że czciciele Najświętszego Serca Jezusowego ofiarowywali wybraną godzinę w ciągu dnia oraz wszystkie uczynki, słowa i myśli w czasie tej godziny na cześć, wynagrodzenie i zadośćuczynienie Sercu Jezusowego za grzechy i zniewagi własne i wszystkich grzeszników. Była to tzw. godzina czuwania w czasie wykonywania pracy fizycznej czy umysłowej. Ofiarowanie tej godziny i pracy w ciągu niej wykonywanej było czcią oddaną Najświętszemu Sercu Jezusowego, z pamięcią o cierpieniach Serca Jezusowego. Modlitwa myślna, ustna, dłuższa lub krótkie akty strzeliste były dla Serca Bożego wynagrodzeniem za tych, którzy Go nie czcili lub znać nie chcieli. Święta czcicieli Serca Jezusowego to pierwszy wtorek po oktawie Bożego Ciała i każdy pierwszy piątek miesiąca. W te dni członkowie Straży Honorowej winni odbyć spowiedź i przystąpić do komunii świętej. Członkowie Straży byli podzieleni na 24 części. Ich zegar zawieszano w kościele przy ołtarzu Najświętszego Serca Jezusowego.

Już w maju 1939 roku obserwowano napiętą sytuację polityczną w świecie. Mimo wszystko mówiono raczej o pokoju niż o wojnie. Parafianie byli zdania, że kościół należy budować, gdyby nawet wybuchła wojna. Wszyscy byli zainteresowani i zaangażowani w tej sprawie, a przygotowania do budowy postępowały. Parafianie wspominali, że rok temu plac kościelny był jeszcze pusty. Obecnie mieli kaplicę, przy której od siedmiu miesięcy funkcjonowała parafia. Ponadto przy parafii stała plebania, stróżówka i budynki gospodarcze. Wszystkie prace i obiekty parafialne wybudowali własnymi rękami i środkami w stosunkowo krótkim czasie, dzięki zaangażowaniu i ofiarności ${ }^{41}$.

Na placu kościelnym gromadzono żwir i kamienie, jako ważny na początek budulec. Na apel proboszcza zwożono i znoszono kamienie nawet na plecach. Miejscowy Zarząd Kolei Żelaznej zaoferował na budowę fundamenty po zniszczonych i spalonych budynkach z I wojny światowej przy torach kolejowych, na terenie kwartału IV i V miasta Brześcia. Komitet Budowy przyjął przedstawioną ofertę, a mieszkańcy zaoferowali pomoc przy kruszeniu fundamentów i wydobyciu kamieni. Pracowali tym liczniej, gdy widzieli swojego proboszcza pracującego wspólnie z parafianami. Do przewiezienia urobionego materiału zgłosili się miejscowi woźnicy z furmankami. Dodatkowo proboszcz zwrócił się o pomoc do dowódców dwóch pułków stacjonujących na Przedmieściu Grajewskim, których żołnierzy wcześniej uczył w gimnazjum „Macierzy”. Przez dwa tygodnie przyjeżdżało ośmiu żołnierzy, którzy parokonnymi wozami zwozili kamienie na plac. Zwiezione kamienie i materiał budowlany usypano w stertę - około $100 \mathrm{~m}^{3}$ budulca, mniej więcej tyle, ile było przewidziane do wykonania fundamentów i podstawy pod nie ${ }^{42}$.

Po Pierwszej Komunii Świętej dzieci w 1939 roku zdecydowano rozpocząć prace budowlane. Należało wykorzystać czas letni, długie dni, okres urlopów i wakacji. Zaproszenie na poświęcenie kamienia węgielnego na Kijówce ksiądz

\footnotetext{
${ }^{41}$ Piątkowski, Kronika parafii, s. 7.

${ }^{42}$ Tamże.
} 
biskup przyjął i wyznaczył datę na 30 VII 1939 roku. Tą informację ogłosił proboszcz wiernym tydzień wcześniej - 23 lipca. Do tego czasu należało wykonać wykopy pod fundamenty. Na apel proboszcza zgłosiło się nazajutrz 120 chętnych z łopatami, zarówno starszych, jak i młodzieży. Inżynier Kozłowski wytyczył dokładne miejsce pod fundamenty o wymiarach budowli 40 metrów długości i 16 metrów szerokości, co uzyskało zatwierdzenie Wydziału Budowlanego magistratu miejskiego. W ciągu jednego dnia został wykonany wykop pod fundament ścian kościoła i częściowo pod wieżę.

Na poświęcenie kamienia węgielnego przyjechał do Brześcia 29 VII 1939 roku biskup Kazimierz Bukraba i zamieszkał na plebanii kościoła pw. Podwyższenia Świętego Krzyża w śródmieściu. Dnia następnego w południe biskup poświęcił kamień węgielny pod tamtejszy poszerzony i wydłużony kościól, a o godzinie 16.00 podobnego poświęcenia dokonał na Kijówce. Dnia poprzedniego, w sobotę, proboszcz ks. Piątkowski z parafianami postawił krzyż kamienny na miejscu wielkiego ołtarza w przyszłym kościele. Spisany na pergaminie akt upamiętniający poświęcenie kamienia węgielnego zawierał nazwiska prezydenta Rzeczypospolitej Ignacego Mościckiego, papieża Piusa XI, biskupa pińskiego Kazimierza Bukraby, dziekana brzeskiego ks. Jana Urbanowicza ${ }^{43}$, proboszcza na Kijówce ks. Wacława Piątkowskiego oraz członków Komitetu Budowy. Podpisany przez wyżej wymienionych został wmurowany w fundamenty. Ostatniego dnia lipca tego roku przystąpiono do zalewania tzw. ławy betonowej pod fundamenty kościoła. Prace te wykonywano ręcznie, przy użyciu dostępnych narzędzi.

\section{Brześć w czasie drugiej wojny światowej}

Dnia 1 IX 1939 roku wybuchła II wojna światowa - Niemcy napadły na Polskę. Polacy mężnie stawiali opór także i w Brześciu. Wielu mieszkańców miasta powtarzało, że Niemcy nie pozostaną tu dłużej, gdyż nastąpi wkrótce ,zmiana warty”. Pierwszy nalot niemiecki na Brześć miał miejsce już 2 września, kolejny 9 września w godzinach popołudniowych. Niemcy dokonywali bombardowań bez konkretnego planu, przeważnie miejsca otwarte. Bomby trafiły w kilka domów mieszkalnych i sklepów w mieście. Chociaż ofiar na Kijówce nie było, ich liczba w mieście wyniosła przeszło 500 zabitych, w tym dzieci i młodzież. Pochowano ich tego samego dnia we wspólnych grobach na ziemi kościelnej przy ul. Jasnej. Niewspółmiernie silniejsze oddziały niemieckie wkroczyły do Brześcia 14 września. Niemcy bombardowali głownie twierdzę Brześć i okoliczne forty. Militarne siły polskie użyte do obrony twierdzy były niewystarczające i liczyły ok. 4.000

${ }^{43}$ Urbanowicz Jan - kapłan archidiecezji wileńskiej. Urodził się w 1895 roku, święcenia kapłańskie otrzymał 6 I 1919 roku w Wilnie. W latach 1923-1929 był prefektem szkół w Kobryniu, a w latach 1929-1933 prefektem Gimnazjum im. R. Traugutta w Brześciu. W 1933 roku mianowany został proboszczem w Niemirowie. Od 1934 od 1938 roku pełnił obowiązki notariusza w Sądzie Biskupim i kierownika Wydziału Metrykalnego Kurii Pińskiej. Od 1938 roku pełnił obowiązki proboszcza parafii Podwyższenia Świętego Krzyża w Brześciu i dziekana brzeskiego. Za pomoc świadczoną partyzantom i Żydom został rozstrzelany przez Niemców w czerwcu 1943 roku w Brześciu. Por. E. Borowski, Martyrologia duchowieństwa diecezji pińskiej w latach 1939-1956, w: Martyrologia duchowieństwa polskiego 1939-1956, Łódź 1992, s. 117. 
żołnierzy pod dowództwem generała brygady w stanie spoczynku Konstantego Plisowskiego. Walczyły one z oddziałami XIX korpusu niemieckiego. Z powodu ograniczonych środków do obrony generał Plisowski postanowił bronić głównie cytadeli. Jego załoga odparła 7 niemieckich natarć. Obrona twierdzy trwała w dniach 14-17 IX 1939 roku, kiedy to kilka dywizjonów artylerii niemieckiej prowadziło nieustanny ogień. W nocy z 16 na 17 września obrońcy postanowili przebić się przez pierścień okrążenia nieprzyjaciela, gdyż zdaniem dowódcy z operacyjnego punktu widzenia dalsza obrona straciła sens. Załoga przeszła na lewy brzeg Bugu i przebiła się na południe. Większość oficerów, obrońców twierdzy brzeskiej w liczbie około stu wraz z gen. Plisowskim, którzy trafili do obozów sowieckich, zgładzono w 1940 roku $^{44}$.

Już 19 września Niemcy poczęli wycofywać się z Brześcia, a ich odwrót trwał trzy dni. Dnia 22 września przed południem wkroczyły do miasta okupacyjne wojska sowieckie, zajmując tereny na wschód od Bugu. Wkrótce nowi okupanci powołali Zarząd Miejski, który zaprowadzał swoje porządki w życiu cywilnym mieszkańców. Pojawiły się także ograniczenia natury religijnej i represje zarówno w stosunku do duchownych, jak i świeckich, co ograniczało pracę duszpasterską. Księża nie mogli, jak dotychczas, uczyć religii w szkołach, a jedynie proboszcz mógł katechizować w kościele. Kapłanom zabroniono odbywania wizyty duszpasterskiej, zwanej kolędą. Po zamknięciu seminarium duchownego i Kurii Biskupiej biskup Kazimierz Bukraba zmuszany do tego przez Rosjan, jeszcze w tym samym roku wyjechał do Lwowa, a stamtąd do Warszawy. Rządy w diecezji przejął wikariusz generalny i sufragan piński bp Karol Niemira, który na skutek nacisków władz komunistycznych i dla uniknięcia zesłania na Syberię, powiadomiony poufnie o planowanym aresztowaniu, $\mathrm{w}$ cywilnym przebraniu przedostał się $\mathrm{w}$ styczniu 1941 roku na teren Generalnego Gubernatorstwa. W drodze do Warszawy odwiedził parafię na Kijówce, odprawił w tamtejszym kościele Mszę świętą i pobyt ten uwiecznił $\mathrm{w}$ formie wspólnej fotografii $\mathrm{z}$ dziećmi i ich opiekunami. W Warszawie mieszkał na terenie parafii pw. św. Wawrzyńca, współpracował ze zbrojnym ruchem oporu oraz angażował się w akcję ratowania Żydów z getta warszawskiego. Podczas Powstania Warszawskiego był kapelanem Armii Krajowej ${ }^{45}$.

${ }^{44}$ Por. Boje Polski 1939-1945. Przewodnik encyklopedyczny, red. K. Komorowski, Warszawa 2009, s. 37-49.

${ }^{45}$ Niemira Karol bp - ur. 28 X 1882 roku w Warszawie w rodzinie ziemiańskiej. Osierocony w wieku 2 lat, wychowywany był przez siostry zakonne. Studiował 1904-1909 w Metropolitalnym Seminarium Duchownym w Warszawie, a dzięki wybitnym zdolnościom skierowany został na Gregorianum, gdzie uzyskał tytuł doktora prawa kanonicznego. Święcenia kapłanskie przyjął w 1911 roku w Warszawie. Pracował jako wikariusz w Łodzi, od 1912 roku w Warszawie; od 1919 roku był kapelanem Wojska Polskiego, od 1920 roku proboszczem archikatedry warszawskiej, od 1925 roku wizytatorem religii w warszawskich szkołach zawodowych. Jako proboszcz parafii św. Augustyna angażował się w prace społeczne i charytatywne w Warszawskim Towarzystwie Dobroczynności i charytatywnym Komitecie Obywatelskim oraz był radnym miejskim Warszawy. W 1933 roku został mianowany sufraganem diecezji pińskiej. Po konsekracji mianowano go wikariuszem generalnym diecezji pińskiej, a od 17 VIII 1933 roku rektorem seminarium diecezjalnego w Pińsku i asystentem 
Materiał budowlany zgromadzony na budowę kościoła na Kijówce władze sowieckie zabrały, skutkiem czego dalsza budowa okazała się niemożliwa. Nikt na razie nie mógł do końca przewidzieć, jakie mogą być następstwa okupacji sowieckiej. Jeszcze w październiku 1939 roku udało się proboszczowi przywieźć ze Szkoły Powszechnej nr 2 przy ul. Krzywej ołtarz św. Stanisława Kostki, który umieszczono w kaplicy, a także komodę do zakrystii.

Rok 1940 był dla wszystkich bardzo ciężki. Nadeszły wyjątkowo silne mrozy, a liczba mieszkańców w mieście malała. Kto mógł, wyprowadzał się na wieś, gdzie spodziewano się łatwiejszego i bezpieczniejszego życia. Mimo, że chleba w mieście nie brakowało, mieszkańcy sukcesywnie wyjeżdżali. Nabożeństwa kościelne odbywały się regularnie, a proboszcz odwiedzał chorych, odprawiał pogrzeby, poświęcał budowane domy, wspierał i pocieszał tych, którzy zdecydowali się pozostać. Ksiądz Piątkowski pracował nie tylko dla parafian, lecz także dla uciekinierów, żołnierzy i jeńców.

Kolejny, 1941 rok zapowiadał się nieco pomyślniej. Ludzie otrzymywali na stałe pracę, $\mathrm{z}$ wyżywieniem nie było zbytnich trudności, powracali niektórzy z zaginionych. Kościół na Kijówce, aczkolwiek mały, zawsze był wypełniony. W uroczystość odpustową Matki Boskiej Królowej Polski tego roku frekwencja na Mszach świętych była wysoka. Trzej księża spowiadali od rana do zakończenia uroczystości.

W pamięci wszystkich mieszkańców Brześcia zapisał się dzień 22 VI 1941 roku hukiem armat od świtu. Wszyscy doskonale rozumieli, że to kolejny nieoczekiwany atak wrogiej armii. Był to początek wojny niemiecko-sowieckiej. Księża uspokajali przerażonych i uciekających mieszkańców, głownie matki z dziećmi na rękach, a mieszkańcy Brześcia kierowali się na wschód - na Kijówkę, gdzie część ludności schroniła się do wykopów pod fundamenty i niewielkiego kościoła. Aby uchronić Najświętszy Sakrament przed ewentualną profanacją, ks. Piątkowski po krótkiej modlitwie spożył Go wraz z wiernymi. Po kanonadzie niemieccy żołnierze przeszukiwali domy i obejścia, poszukując broni. Zjawili się także na plebanii. Przedmieście Kijowskie wyszło z walk o Brześć obronną ręką. Zginął tylko jeden parafianin, zmobilizowany w odległości 5 kilometrów od miasta. Na terenie III Fortu zastrzelono dwóch młodzieńców za nieprzestrzeganie godziny policyjnej. Ponieważ trudno było o trumnę, pochowano ich nazajutrz $\mathrm{w}$ szafie. Teraz ponownie nastąpiła zmiana władzy z sowieckiej na niemiecką. Nabożeństwa odprawiano jak dotychczas. Zabronione było używanie dzwonów, czym można było wywołać alarm, zakazano również poruszania w kazaniach tematów politycznych. Katechizacja nadal odbywała się w kościele. Rekolekcje wielkopostne w 1942 roku odbyły się, a spowiedź organizowano osobno dla mło-

kościelnego Diecezjalnego Instytutu Akcji Katolickiej. Po objęciu przez wikariusza kapitulnego ks. Henryka Humnickiego rządów w diecezji pińskiej pozostającej w granicach Polskiej Rzeczpospolitej Ludowej (w Drohiczynie nad Bugiem) biskup Niemira osiadł w Warszawie. W maju 1945 roku podjął próbę zorganizowania kurii diecezjalnej w Bielsku Podlaskim. Pod koniec życia rezydował w Czubinie k. Błonia, pełniąc posługę biskupią głównie na Ziemiach Odzyskanych. Zmarł 8 VII 1965 roku w Czubinie. Por. Z. Rostkowski, Niemira Karol, w: Encyklopedia Katolicka, t. 13, Lublin 2009, kol. 1138-1139. 
dzieży szkolnej i starszych. Na początku 1942 roku proboszczowie brzescy otrzymali od niemieckiego Zarządu Miasta decyzję o planowanym powiększeniu terenu warsztatów kolejowych w dzielnicy II miasta i poszerzeniu ulicy Smutnej kosztem katolickiego cmentarza grzebalnego. Zarząd Miejski zobowiązał się przenieść ciała pochowanych i ich pomniki za zgodą rodzin zmarłych na wyznaczony plac w pobliżu twierdzy brzeskiej. Odwołania zainteresowanych rodzin do niemieckich władz nie skutkowały. Wiosną tego roku grupa jeńców wojennych pod kierownictwem Niemców rozpoczęła przenoszenie grobów. Rozkopano około 1.000 mogił. Trumien znaleziono o wiele mniej. Kości zmarłych nieznanych pochowano ponownie we wspólnej mogile. Ponieważ nikt z rodzin nie zgodził się na przeniesienie swoich zmarłych i ich pomników na wskazane przez władze miejsce, ciała ekshumowane chowano ponownie na tym samym, i tak już przepełnionym cmentarzu, lecz w innym miejscu.

W czasie wojny niemiecko-sowieckiej Brześć był punktem przeładunkowym dla ludzi i wojska, miejscem kwarantanny oraz formowania czy kompletowania oddziałów kierowanych na front wschodni i do krajów zachodnich. Żołnierze ginęli nie tylko na froncie, ludzkie życie było zagrożone w każdym miejscu. Samoloty niemieckie krążyły nad miastem, zrzucając bomby, więzienia były przepełnione podejrzanymi, często odbywały się egzekucje, ofiarami padali także duchowni. Na początku marca 1943 roku został aresztowany w Brześciu ks. dziekan Jan Urbanowicz.

W tej sytuacji rządca diecezji pińskiej, ksiądz prałat Henryk Humnicki ${ }^{46}$,

${ }^{46}$ Humnicki Henryk - kapłan diecezji mińskiej, następnie pińskiej, od 1913 roku prałat honorowy Mohylewskiej Kapituły Metropolitalnej. Urodził się 14 XI 1873 roku, gimnazjum ukończył w Nowogorodzie i wstąpił do Seminarium Duchownego w Petersburgu, święcenia kapłańskie otrzymał w 1899 roku w Petersburgu. Pracował jako wikariusz w Przydruszku, Rosicy, Witebsku (kościół św. Antoniego). W 1903 roku mianowany został proboszczem w Dawidgródku, skąd władze carskie usunęły go w 1904 roku. Metropolita mohylewski przeniósł go wówczas na urząd proboszcza przy kościele na Cmentarzu Wyborskim w Petersburgu. W latach 1905-1907 był proboszczem w Irkucku, w 1908 roku został przeniesiony na parafię do Hłuska, a po trzech miesiącach został proboszczem w Mozyrzu i dziekanem dekanatu Mozyrsko-Rzeczyckiego. W czasie wojny rosyjsko-niemieckiej zmuszony został do opuszczenia Mozyrza, skąd udał się do archidiecezji gnieźnieńskiej i poznańskiej. W 1921 roku bp Łoziński wezwał go do diecezji i mianował proboszczem w Stolinie, następnie od 1922 roku proboszczem i dziekanem w Łunińcu. Po utworzeniu diecezji pińskiej został mianowany w 1925 roku kanclerzem Kurii Biskupiej Pińskiej i kanonikiem gremialnym Kapituły Katedralnej w Pińsku. Od 1933 roku pełnił obowiązki proboszcza kościoła katedralnego w Pińsku i otrzymał godność prałata-prepozyta tamtejszej Kapituły Katedralnej. Od 1935 roku jako rezydent pełnił obowiązki rektora kościoła filialnego pw. św. Karola Boromeusza (były kościół ojców komunistów) oraz był prefektem szkół średnich i zawodowych w Pińsku. Po zamordowaniu przez Niemców wikariusza generalnego i rządcy diecezji, ks. Witolda Iwickiego († 22 I 1943), obowiązki te przejął ks. Henryk Humnicki. Wysiedlony w 1945 roku z granic Białoruskiej Republiki Socjalistycznej ze wskazaniem Bielska Podlaskiego na miejsce ewakuacji nadal pełnił tam funkcję wikariusza generalnego. Po śmierci bpa Bukraby obrany został przez Kapitułę Pińską wikariuszem kapitulnym, a wybór ten zatwierdziła Stolica Apostolska w dniu 19 IX 1946 roku, nadając ks. Humnickiemu ,wszystkie prawa biskupa rezydencjalnego”, które posiadał do 1950 roku. Na plebanii kościoła Narodzenia Matki Bożej w Bielsku Podlaskim zorganizował Kurię Diecezjalną. Dnia 31 V 
zwrócił się do ks. Piątkowskiego, aby porozumiał się z ks. kan. Janem Breczką ${ }^{47}$, proboszczem w Domaczewie (47 kilometrów od Brześcia) i z ks. kan. Lucjanem Żołądkowskim, proboszczem parafii Peliszcze (30 kilometrów od Brześcia), aby jeden z nich przejął parafię Podwyższenia Świętego Krzyża w Brześciu i urząd dziekana brzeskiego do czasu powrotu ks. Urbanowicza. Obaj księża stanowczo odmówili, thumacząc się względami zdrowotnymi i niebezpieczną sytuacją w Brześciu, m.in. ze względu na bardzo częste bombardowania. Rządca diecezji decyzje ich przyjął. Równocześnie polecił ks. Piątkowskiemu przejęcie obowiązków proboszcza kościoła Podwyższenia Świętego Krzyża i urzędu dziekana z pozostaniem na dotychczasowej parafii na Kijówce. Od tego czasu ks. Piątkowski urzędował w dwóch parafiach. Mieszkał na Kijówce, gdzie odprawiał codziennie Mszę świętą, po czym udawał się rowerem do śródmieścia i tam pozostawał do wieczora dla załatwienia bieżących spraw parafialnych. W tamtym kościele procowało dotychczas dwóch kapłanów - ks. Franciszek Jankowski ${ }^{48}$ i neoprezbiter ks. Jerzy Rosiak ${ }^{49}$, który spełniali obowiązki duszpasterskie od 1 V 1943 r.

1950 roku został zwolniony ze stanowiska wikariusza kapitulnego po mianowaniu nowym administratorem diecezji ks. Michała Krzywickiego. Od początku lipca tego roku przeszedł na emeryturę z rezydencją w Topczewie. Zmarł 17 V 1959 roku w Bielsku Podlaskim i został pochowany przy tamtejszej kaplicy cmentarnej. Borowski, Noty biograficzne o zmarlych kaptanach, s. 221-222; Elenchus ecclesiarum et cleri saecularis ac regularis dioecesis minscensis pro Anno Domini 1924, s. 23, 42; Kościót na Grodzieńszczyźnie, s. 129

${ }^{47}$ Breczko Jan - kapłan diecezji mińskiej, następnie pińskiej. Urodził się w 1881 roku, seminarium duchowne ukończył w Petersburgu, święcenia kapłańskie otrzymał 29 IX 1905 roku. W latach 1905-1914 był prefektem w szkołach w Bobrujsku. Od 1914 roku pełnił obowiązki proboszcza parafii Lubieszów, w dekanacie pińskim. W latach 1921-1926 był rektorem kościoła sióstr benedyktynek w Nieświeżu, następnie w latach 1926-1933 sprawował funkcję rektora kościoła Przemienienia Pańskiego w Nowogródku i prefekta tamtejszych szkół. W 1931 roku mianowany został Kanonikiem Honorowym Kapituły Pińskiej. Od 1933 roku rezydował w parafii Podwyższenia Świętego Krzyża w Brześciu i był prefektem prywatnego gimnazjum żeńskiego Polskiej Macierzy Szkolnej. Po wojnie był proboszczem parafii Hanna w diecezji podlaskiej. Zmarł we Włodawie dnia 8 X 1964 roku, pochowany został 10 października na cmentarzu we Włodawie. Borowski, Noty biograficzne o zmarlych kapłanach diecezji pińskiej, s. 246; Elenchus ecclesiarum et cleri saecularis ac regularis dioecesis minscensis pro Anno Domini 1924, s. 24, 42.

${ }^{48}$ Jankowski Franciszek - kapłan diecezji pińskiej. Urodził się w 1904, święcenia kapłańskie przyjął w 1931 roku. Od 1936 roku pełnił obowiązki wikariusza w parafii Podwyższenia Świętego Krzyża i prefekta szkół powszechnych w Brześciu. Od 1937 roku był nauczycielem religii w szkołach powszechnych, zawodowych i średnich w Pińsku. W 1939 roku przeszedł na takie samo stanowisko do Brześcia. Por. Spis kościołów i duchowieństwa diecezji pińskiej w R. P. 1937, Pińsk 1937, s. $141-142 ; 1938$, s. $143 ; 1939$, s. 147,148 .

${ }^{49}$ Rosiak Jerzy Franciszek - kapłan diecezji pińskiej. Urodził się 24 IV 1914 roku we wsi Strabla, powiat Bielsk Podlaski. Jego rodzice zostali wywiezieni w 1914 roku do Jarosławia w Rosji, skąd powrócili w 1921 roku. W 1936 roku zdał maturę, a w 1937 roku wstąpił do seminarium duchownego w Pińsku. Po jego zamknięciu kontynuował studia seminaryjne pod kierunkiem miejscowych księży. Wobec nieobecności biskupa pińskiego udał się nielegalnie do Łucka na Wołyniu i w dniu 1 V 1943 roku przyjął tam święcenia kapłańskie z rąk bpa Adolfa Szelążka. Po zajęciu w 1944 roku terenów wschodnich przez ZSRR pozostał w Brześciu jako wikariusz parafii Podwyższenia Świętego Krzyża. W tym czasie był jednym z trzech księży pracujących wówczas w Brześciu. 
Ksiądz Piątkowski w dalszym ciągu nie dopuszczał myśli o zaprzestaniu budowy kościoła na Kijowskim Przedmieściu. Na początku 1943 roku dzięki pomocy Stanisława Korbaszewskiego nabył 15 czteroosobowych dębowych ławek. Z przeznaczonych do rozbiórki starych domów murowanych zakupił 20.000 cegieł, które zostały zwiezione na Kijówkę z przeznaczeniem na budowę kościoła.

Tymczasem już od trzech miesięcy przebywał w więzieniu ks. Jan Urbanowicz z Brześcia i ks. Leonard Stanisław Nowak ${ }^{50}$ z parafii Domaczewo. Dnia 22 V 1943 roku ks. Piątkowski zdecydował się interweniować w niemieckim Urzędzie Śledczym, mieszczącym się tuż za ogrodzeniem posesji kościelnej, na terenie II kwartału w Brześciu. W prośbie o zwolnienie księży argumentował, iż są niewinni i bardzo potrzebni wiernym w parafiach. Niemiecki urzędnik w mundurze odparł, że wierzy i ocenia prośbe proszącego, iż księża ci są potrzebni jako duszpasterze, co zaś dotyczy ich niewinności, to zostanie to dokładnie zbadane w ciągu miesiąca. Niestety, miesiąc później, dnia 22 czerwca rozeszła się nieoficjalna, lecz pewna wiadomość, że w tym dniu obaj księża zostali straceni.

W 1944 roku nastąpił odwrót Niemców ze Wschodu pod naciskiem przeważających sił sowieckich z pomocą Wojska Polskiego. W Brześciu Niemcy nie zabraniali ludności wyjeżdżać na Zachód. Od połowy czerwca tego roku następowała stopniowa ewakuacja niemieckiego wojska i sprzętu wojennego. Cofający się Niemcy niszczyli obiekty strategiczne, głównie tory kolejowe, a zwłaszcza zwrotnice. Głośne i silne wybuchy wstrząsały miastem, które formalnie pustoszało, co było widoczne chociażby po frekwencji w kościołach. Dnia 18 VII 1944 roku

Dał się poznać jako ofiarny duszpasterz, szczególnie młodzieży. W 1946 roku rozpoczął odnawianie kościoła. Aresztowany przez MGB 2 VIII 1947 roku, był więziony przez 7 miesięcy w Brześciu i Mińsku. W czasie bardzo ciężkiego śledztwa, przetrzymywany w piwnicy załamał się nerwowo. Za namową współwięźniów przyznał się do śpiewania antysowieckich piosenek. W maju 1948 roku skazany został na karę śmierci, zamienioną na 25 lat łagru o obostrzonym rygorze, 5 lat pozbawienia praw obywatelskich i konfiskatę majątku. Następnie został zesłany do specłagru nr $4 \mathrm{w}$ Norylsku za kołem polarnym (Kraj Krasnojarski). Tam był nieustannie śledzony przez agentów MGB. Przeżył dzięki przysyłanym przez parafian paczkom żywnościowym. Zwolniony po 8 latach, dnia 10 VII 1956 roku, powrócił do diecezji pińskiej 10 września tego samego roku. Po otrzymaniu odmowy rejestracji w Brześciu zatrzymał się w Nieświeżu, gdzie 3 XI 1956 roku uzyskał „sprawkę”. W 1963 roku otrzymał ją na parafię Stołowicze, a od sierpnia 1979 roku na parafię Połoneczka k. Baranowicz. Dojeżdżał okresowo do parafii Iszkołdź, Mir, Nowogródek, Zadwieja. W 1981 roku został napadnięty przed swoim domem i pobity przez „nieznanych sprawców”. Zginął dnia 19 VIII 1984 roku w wypadku samochodowym, staranowany przez pirata drogowego. Pochowany został dnia 22 sierpnia tego roku w Połoneczce. Por. Borowski, Wyższe Seminarium Duchowne Diecezji Pińskiej, s. 142-143; Dzwonkowski, Leksykon duchowieństwa polskiego, s. 517-519; Madała, Polscy księża katoliccy $w$ więzieniach, s. 133.

${ }^{50}$ Nowak Stanisław Leonard - kapłan diecezji pińskiej. Urodził się w 1904 roku, w 1933 otrzymał święcenia kapłańskie. Od 1935 roku był proboszczem w parafii Domaczewo, dekanacie brzeskim. Aresztowany przez Niemców, przebywał w więzieniu w Stołpcach, a następnie przewieziony został do obozu koncentracyjnego w Kołdyczewie (rejon baranowicki) i tam zagazowany dnia 14 XI 1942. Jego nazwisko widnieje na liście więźniów Białystok/Grodno z wyrokiem śmierci z 14 II 1941 roku. Borowski, Wyższe Seminarium Duchowne Diecezji Pińskiej, s. 137-138; Niech świadectwo nie będzie zapomniane, s. 74. 
księża z kościoła w śródmieściu z obawy przez mogącym nastąpić oblężeniem miasta i walkami, udali się do niedalekich Skoków. Ksiądz Piątkowski pozostał na miejscu. Odprawiał w obu kościołach: w śródmieściu i na Kijówce, a na noc przeważnie wracał na Kijówkę. Jego pozostawanie na Kijówce stało się nader niebezpieczne. Zagrożenie powodowało ustawienie rzędu armat niemieckich w odległości 200 metrów od kościoła i plebanii. Pociski artylerii sowieckiej wystrzeliwane w kierunku armat niemieckich przelatywały nad zabudowaniami kościelnymi na Kijówce i łatwo mogły w nie trafić. Mieszkańcy Kijówki znaleźli się zatem między nadciągającą artylerią sowiecką, będącą już w odległości 10 kilometrów, a ustępującą piechotą niemiecką. Parafianie wspólnie z ks. Piątkowskim postanowili wykopać dla własnej ochrony szeroki i odpowiednio głęboki rów, mogący pomieścić kilkanaście osób. Na rów wtoczyli dębowe kloce i w ten sposób powstał prowizoryczny schron. Rosjanie w niedalekiej odległości mieli dobry punkt obserwacyjny i strzelali do każdego, kogo spostrzegli. Sam ksiądz proboszcz znalazł się pewnego razu w niebezpieczeństwie, gdy w jego kierunku wystrzelony został pocisk. Zdążył jednak paść na ziemię, a pocisk padł 20 metrów dalej.

Dnia 28 VII 1944 roku kościół na Kijówce i budynki były pod ciągłym obstrzałem armat. Pocisk armatni uderzył w fundament plebanii, przełamał ją na pół i pogrążył się w piasku pod podłogą. Tego dnia w godzinach wieczornych miał miejsce kolejny silny ostrzał na Forcie III (Tryszyn). Wskutek podmuchu powietrza podniósł się dach na plebanii i wyleciały wszystkie szyby. Tego dnia późnym wieczorem Rosjanie zdobyli Brześć. Nazajutrz, 29 lipca ks. Piątkowski z grupą kilkudziesięciu osób odprawił dziękczynną Mszę świętą za ocalenie. Mimo pięciodniowego ostrzału Kijówki ofiar w ludziach nie było. Tego dnia zaraz po Mszy świętej ksiądz proboszcz udał się pośpiesznie do śródmieścia, gdyż nie był w tej części miasta przez ostatnie pięć dni walk o miasto. Na plebanii spotkał odpoczywających żołnierzy sowieckich. Zauważył, że w poszczególnych pokojach brakowało już wielu przedmiotów. W kościele szyby były wybite, a ramy okienne w większości połamane. Po trzech dniach powrócił ze Skoków ks. Jerzy Rosiak. Natomiast ks. Franciszek Jankowski wyjechał na Zachód, za Bug. Po przejściu frontu w kościele dokonano w ciągu miesiąca prowizorycznego remontu, łącznie $\mathrm{z}$ pomalowaniem ścian, w co zaangażowali się parafianie. Również na Kijówce wstawiono szyby w kościele i na plebanii. Okazało się, że nie wszyscy parafianie wyjechali za Bug. Wielu opuściło miasto tylko na czas przewidywanych walk o miasto, chroniąc się w sąsiednich wioskach. Teraz powracali do swoich domostw i cieszyli się najbardziej widokiem księdza. Ze względu na dużą frekwencję wiernych z miasta i okolicy w kościele Podwyższenia Świętego Krzyża ks. Piątkowski zmuszony był odprawiać więcej Mszy świętych, a na Kijówce tylko jedną, na którą także przybywało mnóstwo wiernych.

\section{Posługa pastoralna ks. Piątkowskiego w diecezji pińskiej po 1945 roku}

Już w czasie wojny na terenie diecezji pińskiej nie przebywał żaden biskup katolicki. W tej sytuacji ważne pozostawały nominacje wikariuszy generalnych. Po wyjeździe biskupów do Polski w diecezji pińskiej było dwóch wikariuszy ge- 
neralnych: w Bielsku Podlaskim i w Pińsku. Białoruskim terenem diecezji pińskiej zarządzał jako wikariusz generalny ks. prałat Witold Iwicki. Po jego śmierci obowiązki te od 22 I 1943 roku przejął ks. Henryk Humnicki, a po jego wyjeździe do Polski w 1944 roku - proboszcz katedry pińskiej, ks. Jan Wasilewski. Po aresztowaniu w 1945 roku, zesłaniu (od maja 1947) i śmierci (9/10 III 1948) ks. Wasilewskiego w Kraju Krasnojarskim, wikariuszem generalnym diecezji pińskiej pozostającej w granicach ZSRR został ks. Jan Borysiak. Po jego aresztowaniu i wywiezieniu na zesłanie zastąpił go w 1947 roku ks. Wacław Piątkowski, proboszcz z Brześcia, a od lutego 1948 roku - parafii świętych Apostołów Piotra i Pawła w Niedźwiedzicy ${ }^{51}$.

Wyzwolenie terenów Białoruskiej SRR z okupacji niemieckiej odbywało się w dwóch etapach. Pierwszy na przełomie 1943/1944 roku, kiedy Armia Czerwona zajęła wschodnią i południową część Białorusi, drugi zaś rozpoczął się 22 VI 1944 roku, gdy wyzwalano główne miasta: Mińsk - 3 lipca, Grodno - 16 lipca, Brześć - 28 lipca. W walkach tych brała udział 1. Armia Polska im. T. Kościuszki pod dowództwem płk. Zygmunta Berlinga, która swoją pierwszą walkę stoczyła pod Lenino.

W trudnej i niestabilnej sytuacji powojennej byłych Kresów Kościół pozostawał jedyną instytucją oferującą trwałe wartości, był skrawkiem „byłej Polski”, siłą jednoczącą Polaków i gwarantem ich tożsamości religijnej. Stąd podstawowym zadaniem władz komunistycznych, w tym głównie pełnomocników Urzędu ds. Kultów Religijnych, było przeprowadzenie rejestracji wspólnot religijnych i świątyń. Wprowadzenie takiej ewidencji spotkało się z bojkotem tamtejszego duchowieństwa. W obwodzie brzeskim odmówili rejestracji księża: Jerzy Rosiak, Wacław Piątkowski i Józef Wasilewski ${ }^{52}$.

Z istniejących do 1939 roku trzech kościołów parafialnych i pięciu kaplic publicznych w Brześciu, po wojnie funkcjonowała jedynie parafia na Kijowskim Przedmieściu z kaplicą, którą udało się wiernym zarejestrować w dniu 28 XII 1947 roku. Pozostałe kościoły zostały zamknięte.

W 1945 roku rozpoczęła się tzw. repatriacja ludności polskiej, zamieszkałej dotychczas na tamtych terenach, na Zachód, za Bug. Wpływała ona na sytuację

${ }^{51}$ Zarówno w czasie okupacji niemieckiej, jak i w zmienionych po 1945 roku warunkach politycznych nominacje te odegrały istotną rolę w funkcjonowaniu Kościoła katolickiego na tamtych terenach. Wikariusze generalni pełnili władzę kościelną w pełnym tego słowa znaczeniu. Byli więc władzą nie tylko dla innych pracujących tam kapłanów, ale, co istotne, w momencie ich mianowania otrzymali prawo mianowania swoich następców, a przez to ich władza trwała do momentu pełnego obsadzenia hierarchii katolickiej na tych terenach diecezji pińskiej, które znalazły się w państwie Białoruś. Por. R. Dzwonkowski, Leksykon duchowieństwa polskiego represjonowanego w ZSRR 1939-1988, Lublin 2003, s. 476-477; Madała, Kościól w niewoli, s. 9-10.

${ }^{52} \mathrm{~W}$ przypadku rejestracji parafii katolickiej wymagano: podania wiernych o rejestrację, podpisów co najmniej 20 osób, kwestionariusza i życiorysu duchownego oraz listy ewidencyjnej księży danego dekanatu. Po otrzymaniu wymaganych dokumentów urząd przystępował do drugiego etapu: ułożenia protokołu odbiorczego, zawarcia umowy z parafią o przekazanie jej budynku kościoła w nieodpłatne i bezterminowe korzystanie, a także sporządzenia inwentarza majątku kościelnego. Stąd rejestracja parafii była ze strony komunistów wymuszoną koniecznością na rzecz ludzi wierzących - katolików. 
Kościoła i wyglądała różnie, w zależności od obszaru ${ }^{53}$. Korzystała z niej głównie ludność napływowa, rzadziej decydowali się opuszczać rodzinne strony Polacy mieszkający tam od pokoleń. Ksiądz Piątkowski ogromnie przeżywał wyjazdy księży za Bug oraz opuszczanie przez nich parafii. Oceniał je negatywnie i na wszelkie możliwe sposoby przeciwdziałał zwłaszcza wyjazdom księży, a opuszczone przez nich parafie w miarę możliwości obsługiwał sam lub organizował opiekę duszpasterską dla parafian pozostawionych przez duszpasterzy, czując się za nich odpowiedzialny jako dziekan ${ }^{54}$ i wikariusz generalny diecezji pińskiej pozostającej w granicach Republiki Białoruskiej. Znał doskonale sytuację, gdyż przychodziły do niego depesze i przyjeżdżały delegacje z parafii opuszczonych przez księży. Dnia 15 V 1947 roku ks. Piątkowski poleciał samolotem z Brześcia do Iwieńca, by powstrzymać wyjazd tamtejszych księży. Usłyszał od nich odpowiedź: „Ksiądz chce, by nas na Sybir wywieźli”.

Niektórzy z duchownych w ramach repatriacji opuszczali swoje parafie dobrowolnie, inni pod naciskiem władz, co zdarzało się często zwłaszcza w parafiach przygranicznych. Jako pierwszy już w styczniu 1945 roku wyjechał proboszcz z Kamieńca Litewskiego. Drugi kapłan opuścił w marcu parafię Domaczewo. Już w czasie okupacji niemieckiej cztery parafie pozostawały bez duszpasterzy. Tego roku przez Brześć przekroczyło granicę kilkudziesięciu księży. Ci nie rozpaczali, nie skarżyli się, że zostawili swoich parafian, a raczej cieszyli się że udało im się wydostać. Tak w 1946 roku zmniejszyła się liczba kapłanów nie tylko w dekanacie brzeskim, lecz także w pozostałych w granicach Białoruskiej Socjalistycznej Republiki Radzieckiej ${ }^{55}$.

W zimie 1945/46 roku coraz bardziej zapadał na zdrowiu ks. Żołądkowski, proboszcz parafii Peliszcze, który obsługiwał także parafię Kamieniecką ${ }^{56}$. Nie

${ }^{53}$ Gdy w 1945 roku okazało się, że tereny wschodnie II Rzeczypospolitej znalazły się w granicach ZSRR, po straszliwych rzeziach ludności polskiej przeprowadzonej przez UPA na Wołyniu Polacy uciekali na Zachód. Podobnie było w Galicji. Inna była sytuacja na Białorusi, gdzie nie było wrogości do Polaków, stąd ludność wiejska nie chciała wyjeżdżać, wierząc w sprawiedliwość dziejową i powrót Polski na te tereny. Dlatego początkowo ogół ludzi, mimo wszystko, nie zamierzał wyjeżdżać. Tylko inteligencja, obawiając się Sowietów, wyjeżdżała natychmiast. O postawach innych decydowała polityka sowiecka na tych terenach. Por. Za wschodnia granica 1917-1939, Warszawa 1995, s. 168.

${ }^{54}$ Ksiądz Piątkowski, pracujący w Brześciu z ks. Jerzym Rosiakiem, został wezwany przez władze i był namawiany do wyjazdu wraz z parafianami specjalnie podstawionym pociągiem. Por. Za wschodnia granica, s. 169, 178.

${ }^{55}$ Po opuszczeniu w latach 1945-1947 diecezji pińskiej przez część duchowieństwa i wiernych w 126 parafiach pozostały czynne 42 kościoły z 51000 katolików. W 1957 roku czynnych było 25 kościołów, obsługiwanych przez 13 księży.

${ }^{56}$ Kamieniec Litewski - miejscowość w dawnym województwie brzesko-litewskim nad rzeką Leśną. W 1383 roku książę Jagiełło odzyskał Kamieniec z rąk Janusza Mazowieckiego, a później, w 1390 roku walczył o twierdzę kamieniecką ze swoim bratem Witoldem. Tamtejszy zamek został zniszczony w czasie wojny polsko-moskiewskiej 1654-67 i odbudowany w 1771 roku, istniał jeszcze w XIX wieku. Okrągła wieża z cegły została odrestaurowana w 1903 roku, a od 1960 roku mieści się w niej muzeum krajoznawcze. Por. Encyklopedia Kresów, red. M. Karolczuk, Kraków 2004, s. 177. 
był zdolny wygłosić w swoich parafiach rekolekcji wielkopostnych w 1946 roku. Wyręczył go ks. Piątkowski. Parafianie z Kamieńca i Peliszcz prosili dziekana księdza Piątkowskiego o zapewnienie im opieki duszpasterskiej. Tymczasem ks. Żołądkowski w końcu kwietnia 1946 roku przyjechał na leczenie do Brześcia, z myślą, że po wyleczeniu powróci do Peliszcz. Jednak choroba nowotworowa niszczyła jego zdrowie. Na początku lipca tego roku zmarł. Został pochowany na cmentarzu w Brześciu przy niewielkiej kaplicy. Do Kamieńca i Peliszcz dojeżdżał $\mathrm{z}$ niedzielną posługą duszpasterską ks. Piątkowski na zmianę z ks. Jerzym Rosiakiem, którzy odprawiwszy w Brześciu Msze święte udawali się do parafii Peliszcze, a następnie do Kamieńca Litewskiego. Dojeżdżali rowerem, rzadziej furmanką. Najczęściej czekali na szosie aby zabrać się okazyjnie ciężarówką. W końcu grudnia 1946 roku wyjechał za Bug ks. Wincenty Chwojnowski ${ }^{57}$ z Czernawczyc, a na jego miejsce przybył wkrótce ze Szczytnik ks. Antoni Grzybowski. Było to słuszne posunięcie, gdyż w Szczytnikach pozostało niewielu parafian, w przeciwieństwie do Czernawczyc, z dużym i zabytkowym kościołem. Jednak ubytki kapłanów były widoczne na każdym kroku. W sierpniu 1947 roku zniknął współpracownik dziekana, ks. Jerzy Rosiak. Po kilku dniach okazało się, że jest więziony. W tej sytuacji ks. Piątkowski zamieszkał na plebanii w śródmieściu. Odprawiał jak dotychczas zarówno tam, jak i na Kijówce, a parafie Kamieniec i Peliszcze przejął ks. Antoni Grzybowski z Czernawczyc.

Niebawem nadeszła wiadomość, że proboszczowie z parafii Rubieżewicze, Wołma i Iwieniec zdecydowali wyjechać do Polski, pozostawiając parafie, których wierni poprosili dziekana brzeskiego o opiekę duszpasterską. Ksiądz Piątkowski po naradzie z ks. Stanisławem Łazarem ${ }^{58}$, proboszczem na Przedmieściu

${ }^{57}$ Chwojnowski Wincenty - kapłan diecezji pińskiej. Urodził się w 1884 roku, święcenia kapłańskie przyjął w 1918 roku w Wilnie. W latach 1923-1935 był proboszczem parafii Zbirogi w dekanacie kobryńskim. Tutaj odbudował spalony kościół, plebanię i budynki gospodarcze. Na terenie parafii, w Żabince, zorganizował kaplicę. W 1935 roku mianowany został proboszczem kościoła parafialnego Przenajświętszej Trójcy w Czernawczycach. W 1939 roku rewindykował kościół pocysterski w Wistycach na terenie tej parafii, zamieniony w okresie porozbiorowym na cerkiew. Pod koniec grudnia 1946 roku wyjechał do Polski, a na jego miejsce przybył ks. Antoni Grzybowski. Ks. Chwojnowski pracował w diecezji wrocławskiej do przejścia na emeryturę w 1962 roku. Zamieszkał wówczas w Ciechocinku i tu zmarł 22 II 1964 roku. Por. Borowski, Noty biograficzne o zmarlych kaptanach diecezji pińskiej, s. 242.

${ }^{58}$ Łazar Stanisław - kapłan diecezji pińskiej. Urodził się w miejscowości Domnaty koło Białegostoku, w wielodzietnej rodzinie chłopskiej. W 1921 roku rozpoczął naukę w salezjańskim gimnazjum klasycznym w Różanymstoku. Po piątej klasie przeniósł się do Pińska, gdzie w 1929 roku zdał maturę i wstąpił do Seminarium Duchownego. Święcenia kapłańskie otrzymał w 1935 roku w Pińsku z rąk bpa Kazimierza Bukraby. Przez kilka miesięcy pracował jako wikariusz parafialny w Kobryniu, następnie w Iwieńcu (1935-37), Prużanach (1937-38) i Brześciu (od 1938 roku jako prefekt szkół). Po proboszczu ks. Antonim Rojku pełnił czasowo (od 24 III od 21 IV 1939) obowiązki proboszcza w Prużanach. W czasie okupacji był proboszczem w Brześciu na Grajówce i tam prowadził tajne nauczanie polskie. Aresztowany przez Niemców 14 VII 1943 roku, przetrzymywany był w brzeskim więzieniu niemieckim do 14 I 1944 roku. W 1947 roku pracował bez rejestracji w kościele Najświętszego Serca Pana Jezusa na Grajewskim Przedmieściu. Aresztowany przez NKWD w nocy z 28 na 29 IX 1948 roku, skazany został, m.in. za krytykę kołchozów, dnia 9 listopada tego 
Grajewskim w Brześciu, i ks. Antonim Grzybowskim z Czernawczyc zdecydował wyjechać do Rubieżewicz ${ }^{59} \mathrm{w}$ powiecie stołpeckim. Po uzyskaniu pozwolenia na pracę w tamtejszym powiecie ks. Piątkowski wyjechał dnia 22 X 1947 roku z Brześcia. Od tego momentu proboszczem trzech parafii brzeskich: Podwyższenia Krzyża Świętego, Matki Bożej Królowej Korony Polskiej i Najświętszego Serca Pana Jezusa, został ks. Stanisław Łazar. W Rubieżewiczach ks. Piątkowski planował pozostać na stałe, co jednak okazało się niemożliwe ze względu na szykany władz komunistycznych i problemy z komitetem kościelnym. Pracował tam bardzo krótko, od 23 X 1947 do 20 II 1948 roku. Dnia 26 II 1948 przeszedł do parafii Niedźwiedzica koło Baranowicz, którą już wcześniej obsługiwał. Ostatnim duszpasterzem w tej parafii w czasie wojny był ks. Leon Bujnowski, aresztowany i rozstrzelany przez Niemców ${ }^{60}$. Od Wielkanocy 1948 roku dojeżdżał także ks. Piątkowski do Nowogródka, gdzie nie było kapłana. Pomimo zakazu władz

roku na 10 lat łagrów i 5 lat pozbawienia praw obywatelskich. Po 10 miesięcznym pobycie w więzieniu w Brześciu wywieziony został 12 IV 1949 roku do Minłagu w Incie, w Republice Komi, gdzie pracował w kopalni węgla kamiennego. Po wypadku przy pracy przeniesiony został na powierzchnię. Od 1951 roku przeniesiono go do łagru koło Uchty, gdzie pracował przy wyrębie lasu. Zwolniony został dnia 14 VII 1954, po sześciu latach odbywania kary. Otrzymawszy po 40 dniach dowód osobisty, powrócił do Brześcia. Dzięki staraniom tamtejszych wiernych otrzymał 28 III 1955 roku „sprawkę” do pracy przy jedynej czynnej kaplicy na Kijówce (ul. Swietłaja 29). Pozbawiony prawa pracy duszpasterskiej 4 VI 1959 roku, pracował przy budowie mostu, później przy naprawie dróg, a od sierpnia 1962 roku jako ładowacz książek w magazynie. W listopadzie tego roku zwolniony z pracy, przeszedł na całkowite utrzymanie parafian. Nie będąc zarejestrowanym, ksiądz Łazar chodził do kościoła jak pozostali wierni, którzy nieustannie zabiegali u władz o jego rejestrację, którą otrzymał dopiero po ponad 5 latach. W Brześciu pracował do śmierci, która nastąpiła 20 XII 1988 roku. Pochowany został na cmentarzu komunalnym w Brześciu. Liturgię pogrzebową odprawił ks. prałat Kazimierz Świątek w asyście kapłanów przybyłych z Polski. Por. AAD, Zespół Archiwum Parafii Brześć, Sygn. IV/Ps/1, Akta personalne ks. Stanisława Łazara, Kanclerz Kurii Pińskiej do ks. Stanisława Łazara z 24 III 1939 (L. 1082/39), Biskup piński o ks. Łazarze z 15 IV 1939 (L. 1319/39). Por. Borowski, Wyższe Seminarium Duchowne Diecezji Pińskiej, s. 140, 142; Dzwonkowski, Leksykon duchowieństwa polskiego, s. 383-386.

${ }^{59}$ Pierwszy kościół w Rubieżewiczach pochodził z 1779 roku. Obecny, murowany, wybudowany staraniem parafian w latach 1906-1910, konsekrowany został pw. Świętego Józefa w 1921 roku przez biskupa mińskiego Zygmunta Łozińskiego. Ambonę ufundowała w 1912 roku Rozalia Czeretowa, organy w 1928 roku wykonał Wacław Bernacki z Wilna, a ołtarz główny przywieziono w 1935 roku z Wilna. Po wojnie kościół w Rubieżewiczach był czynny nieprzerwanie. Por. Elenchus ecclesiarum et cleri saecularis ac regularis dioecesis minscensis pro Anno Domini 1924, s. 30; Por. W. W. Żurek, Jeńcy na wolności. Salezjanie na terenach bytego ZSRR po II wojnie światowej, Kraków 1998, s. 23.

${ }^{60}$ Bujnowski Leon - kapłan diecezji pińskiej. Urodził się w 1891 roku. Po ukończeniu seminarium duchownego w Petersburgu otrzymał tam w 1917 roku święcenia kapłańskie. Następnie był wikariuszem w Moskwie. Około 1919 roku został aresztowany, a w 1924 roku zwolniony w drodze wymiany więźniów z Polską. Od 1925 roku był proboszczem parafii w Iwieńcu w diecezji pińskiej. W 1934 roku podjął obowiązki rektora kościoła w Siniawce, w parafii Niedźwiedzica. Aresztowany przez Niemców 27 VI 1943 roku, został wywieziony do Baranowiczach, a następnie rozstrzelany 13 VII 1943 roku w obozie Kołdyczewo k. Baranowicz. Por. Madała, Polscy księża katoliccy w więzieniach, s. 30. 
pełnił funkcję dziekana i niestrudzenie nakłaniał księży do pozostania na miejscu, by nie osieracać tamtejszych parafii ${ }^{61}$.

W nocy z 19 na 20 I 1950 roku ks. Piątkowski został aresztowany w Niedźwiedzicy. Początkowo więziony był w Baranowiczach, a po trzech miesiącach, od 10 kwietnia (Wielkanoc) przewieziony został do więzienia w Mińsku. Tam, poddawany torturom, przechodził ciężkie śledztwo. Został oskarżany o rzekome szpiegostwo na rzecz Watykanu. Przez kilka miesięcy przetrzymywany był w celi bez okna. Jego posiłek stanowił kawałek chleba i kubek gorącej wody. Przez 18 dni pozbawiony był snu w ciągu dnia i przetrzymywany w zawilgoconym karcerze o wymiarach metr na metr. Na skutek takich warunków po 8 dniach stracił przytomność. Wezwany lekarz więzienny stwierdził śmiertelne wymęczenie i wyniszczenie organizmu. W końcu lipca przeniesiony został z więzienia śledczego do ogólnego. Nie podpisał przyznania się do winy, czego domagali się śledczy. Dnia 2 X 1950 roku, wyrokiem Kolegium Specjalnego przy GPU ${ }^{62}$ ks. Piątkowski skazany został, bez przewodu sądowego i możliwości obrony, na 10 lat łagrów. Etapami, przez Moskwę, Swierdłowsk i Pietropawłowsk Kamczacki deportowano go do stiepłagu w Kenigrze w Kazachstanie, gdzie dotarł 2 II 1951 roku. Od listopada tego roku przebywał w łagrze specjalnym numer SDD-204 dla więźniów politycznych w Dżezkazganie ${ }^{63}$. Otrzymywane od parafian z Niedźwiedzicy paczki żywnościowe ułatwiały mu przeżycie. W łagrze ks. Piątkowski odprawiał potajemnie Msze święte dla grupy Polaków i spowiadał. Często udawało mu się zmylić czujność ochrony łagru, a wówczas w nocy wymykał się poza obóz, aby służyć posługą duszpasterską w sąsiednich wioskach, gdzie mieszkali zesłańcykatolicy $^{64}$. Od 4 I 1956 roku był czasowo zwolniony z łagru jako inwalida i skierowany do ośrodka dla inwalidów Tierkiety ${ }^{65}$.

Jeszcze przed aresztowaniem ks. Piątkowskiego w 1950 roku władze usiłowały zamknąć kościół w Niedźwiedzicy i przeznaczyć go na magazyn. Parafianie jednak nie dopuścili urzędników, kładąc się krzyżem przed wejściem do świątyni. Po aresztowaniu proboszcza ukryto klucze do drzwi kościelnych i przez cały czas trzymano przy kościele wartę. W dzień pilnowały kobiety, a nocą mężczyźni z psami i kijami w ręku. Trwało to cały rok i w tym czasie nie otwierano kościoła, a ludzie modlili się przed zamkniętymi drzwiami. W ten sposób wierni obronili, zarejestrowany 24 II 1948 roku, kościół przed zajęciem go i przeznaczeniem na

${ }^{61}$ Por. Dzwonkowski, Leksykon duchowieństwa polskiego, s. 473-474.

${ }^{62}$ OSO (ros. Osoboje Sowieszczanije) - Kolegium Specjalne przy sowieckim GPU (ros. Gosudarstwiennoje Politiczieskoje Uprawlenije - Państwowy Zarząd Polityczny), powołane do sądzenia więźniów politycznych. Był to pozasądowy organ represyjny, orzekający zaocznie w trybie administracyjnym. Działało w latach 1922-1953 jako jedno z głównych narzędzi terroru, masowo wydające wyroki śmierci i zesłania do łagrów.

${ }^{63}$ Dżezkazgan (kazachski Żezkazgan) - miasto w środkowym Kazachstanie (obwód karagandyjski) nad rzeką Karaga-Kengir. Założone w 1954 r. po powstaniu więźniów w pobliskim gułagu Kengir. Posiada połączenie kolejowe z Karagandą oraz port lotniczy.

${ }^{64}$ Mieszkali w nich zesłańcy, którzy odbyli wprawdzie karę łagru, nie mieli jednak prawa powrotu do miejsc zamieszkania, stąd z konieczności musieli tam pozostać.

${ }^{65}$ Por. Dzwonkowski, Leksykon duchowieństwa polskiego, s. 476. 
cele niekultowe lub przed zniszczeniem ${ }^{66}$. Po śmierci Stalina w 1953 roku i upadku Ławrientija Berii ${ }^{67}$ rozpoczął się w ZSRR proces odchodzenia od najdrastyczniejszych metod prześladowania obywateli. Areszty i łagry opuszczali pierwsi więźniowie, w tym także księża katoliccy. Większość z nich usiłowała powrócić do dawnych parafii, by kontynuować $\mathrm{w}$ nich przerwaną $\mathrm{z}$ konieczności pracę duszpasterską. Mimo trudności ze stron władz lokalnych w uzyskaniu zameldowania i pozwolenia na wykonywanie czynności kapłańskich (tzw. sprawki), gdyż władze obawiały się powrotów księży łagierników ze względu na ich popularność podbudowaną doznanym cierpieniem, ks. Piątkowski po 7 latach łagru został zwolniony z zesłania w dniu 6 IV 1956 roku. Dnia 29 maja przybył do Baranowicz, skąd po kilku dniach przyjechał do Niedźwiedzicy. Tam witany był z nieopisaną radością i entuzjazmem. Dzięki staraniom wiernych dnia 4 VII 1956 roku otrzymał „sprawkę", a 22 lipca tego roku zameldował się, co dawało mu możliwości pracy duszpasterskiej. Na początku ogłosił wiernym, że ma władzę biskupiego wikariusza generalnego ${ }^{68}$, z której korzystał, nie bacząc na pogróżki i zastraszenia władz. W części diecezji, pozbawionej realnych możliwości rządów biskupa ordynariusza, ks. Wacław odpowiadał za koordynację działalności duszpasterskiej. Organizował przez wiele lat potajemnie dni skupienia dla kapłanów tej diecezji, co miesiąc $w$ innej parafii.

W 1960 roku sekretarz Partii Komunistycznej BSRR - Aleksandr A. Smirnow, sugerował pełnomocnikowi Rady ds. Religii obwodu brzeskiego przeniesienie ks. Piątkowskiego do jakiejkolwiek innej parafii, tłumacząc że duszpasterz ten ma duży autorytet u miejscowych wiernych. Niezmordowanie zapewniał opiekę

${ }^{66} \mathrm{~W}$ czasie zesłania ks. Piątkowskiego na skutek kłamliwych agitacji komunistów niektórzy parafianie dopuścili się grabieży na parafii. Por. Za wschodnia granica, s. 224.

${ }^{67}$ Ławrientij Pawłowicz Beria (1899-1953) - szef NKWD. Był jednym z najbliższych współpracowników Józefa Stalina, w znacznym stopniu odpowiedzialnym za wielkie czystki okresu stalinowskiego, w tym za zbrodnię katyńską. Urodził się w rodzinie chłopskiej w Abchazji. Po ukończeniu technikum studiował inżynierię w Baku. Tam w 1917 roku wstąpił do partii bolszewickiej, następnie do CzeKa, poprzedniczki NKWD. Od początku był popierany przez Stalina jako jego krajan. W 1926 roku został sekretarzem partii w Gruzji. Od 1935 roku był jednym z najbardziej zaufanych ludzi Stalina. Po odsunięciu i aresztowaniu szefa NKWD Nikołaja Jeżowa, Beria zajął jego miejsce. Zreorganizował Główny Urząd Obozów Pracy, tzw. Gułag. Nadzorował także masowe deportacje ludności, w tym ponad milina Polaków z terenów zajętych przez ZSRR (1939-1941). W latach 1941-1953 zajmował stanowisko wicepremiera. W 1945 roku został awansowany na marszałka ZSRR, a w 1946 roku został członkiem Biura Politycznego. Po śmierci Stalina był jedną z najpotężniejszych postaci w sowieckim aparacie władzy. Obalony został przez Chruszczowa, Malenkowa i Mołotowa. Po krótkim procesie został skazany na śmierć i zgładzony. Por. I. Mikłaszewicz, Polityka sowiecka wobec Kościoła katolickiego na Litwie 1944-1965, Warszawa 2001, s. 115.

${ }^{68}$ W dniu 31 XII 1946 roku wikariusz kapitulny ks. prałat Henryk Humnicki mianował ks. Piątkowskiego wikariuszem generalnym tej części diecezji pińskiej, która pozostała w Związku Radzieckim. W 1957 roku otrzymał on jednak ponownie od władz komunistycznych zakaz wykonywania funkcji dziekana pod groźbą utraty rejestracji. Ponadto z upoważnienia administratora apostolskiego diecezji pińskiej, pozostającej po 1945 roku w Rzeczypospolitej Polskiej, ks. infułata Michała Krzywickiego, który od 1950 roku rezydował w Drohiczynie, ks. Piątkowski był administratorem diecezji pińskiej w Białoruskiej SRR. 
duszpasterską wiernym z zamkniętych przez komunistów sąsiednich parafii Hancewicze, Krzywoszyn, Lachowicze, Lipsk i Łuniniec. Ponadto na święta i przy innych okazjach przyjeżdżali do Niedźwiedzicy wierni zza przedwojennej granicy wschodniej: Bobrujska ${ }^{69}$, Mohylewa, Słucka i innych, by tu skorzystać z posługi sakramentalnej kapłana. W 1967 roku ks. Piątkowski pozbawiony został na kilka tygodni - od 17 stycznia do 6 marca - ,sprawki”. Od 25 XII 1980 roku do 1984 roku dojeżdżał do parafii Nowa Mysz koło Baranowicz, gdzie odprawiał Mszę świętą w sobotę i niedzielę rano, a następnie udawał się do swojej parafii.

Wobec utrzymywanego przez lata zakazu przyjmowania kandydatów do seminarium duchownego w Rydze ${ }^{70}$ ks. Piątkowski od 1960 roku potajemnie przygotowywał kandydatów do kapłaństwa w starej plebanii w Niedźwiedzicy. Trwało to przez kilka lat i była to jedyna tego rodzaju inicjatywa na Białorusi. Po jakimś czasie KGB wyśledziło ks. Piątkowskiego i zaczęły się wezwania do Brześcia i zakazy. Czasem przyjeżdżały niespodziewane kontrole, a kandydaci chronili się ucieczką do lasu. Wpadki nie było. Ówczesna gospodyni na plebanii Zofia Sokołowska z Mińska chodziła wieczorami wokół plebanii i pilnowała jej. Kandydaci do kapłaństwa zatrudnieni byli jako palacze centralnego ogrzewania w pobliskich Lachowiczach. Po przepracowanej całej dobie mieli dwie doby wolne od pracy ${ }^{71}$. Spośród jego kandydatów przedstawionych biskupom dziesięciu otrzymało święcenia kapłańskie. Do ich grona należał także ks. Antoni Dziemian$\mathrm{ko}^{72}$, obecnie biskup na Białorusi. Przygotowanie owych kandydatów oceniali

${ }^{69}$ Bobrujsk - miasto w dawnym województwie mińskim nad Berezyną. Od XIV wieku osada położona w Wielkim Księstwie Litewskim miała charakter obronny przed Tatarami i Kozakami. W 1630 roku jezuici założyli tu stałą misję, której przewodniczył św. Andrzej Bobola. Wybudowany przez nich kościół spalili w 1651 roku Kozacy. Jezuici powrócili do Bobrujska w 1681 roku i w następnym stuleciu wybudowali kościół. Po kasacie zakonu w 1773 roku klasztor opustoszał. Pozostałości jego zabudowań władze rosyjskie wykorzystały przy wznoszeniu nowej twierdzy w 1807 roku. Podczas wojny polsko-bolszewickiej w 1919 roku Polacy rozbili tu oddziały sowieckie i weszli do miasta. W okresie międzywojennym Bobrujsk pozostał poza granicami Polski. W latach 1941-42 hitlerowcy zamordowali w Bobrujsku 40 tysięcy jeńców, głównie sowieckich. Por. Encyklopedia Kresów, s. 47.

${ }^{70}$ Drugie na terenie całego ZSRR seminarium duchowne w Kownie przyjmowało jedynie kandydatów z Litewskiej SRR. W 1978 roku 27 księży wystąpiło oficjalnie do władz białoruskich w sprawie otwarcia seminarium duchownego na Białorusi, jednak bez skutku. Por. Za wschodnia granica, s. 259-260.

${ }^{71}$ Predyspozycje ks. Piątkowskiego do roli formatora przyszłych kapłanów potwierdza ks. Roman Dzwonkowski, który przekonał się o nich, będąc u niego przez tydzień z pomocą duszpasterską w okresie Świąt Wielkanocnych 1990 roku, kiedy widział, jak godzinami modlił się ks. Piątkowski w nieogrzewanym kościele. Do tej pracy posiadał przygotowanie intelektualne: studia w Rzymie ukończone doktoratem, znajomość języków obcych i gry na organach. Dysponował także przedwojennymi podręcznikami seminaryjnymi. Por. Za wschodnia granica, s. 257-258.

${ }^{72}$ Dziemianko Antoni (Diemjanko Antonij) bp - urodził się w miejscowości Zabrodzie w parafii Derewna na Białorusi, w archidiecezji mińsko-mohylewskiej. Po ukończeniu w 1977 roku szkoły średniej w rodzinnej miejscowości, na skutek sprzeciwu władz w Mińsku nie został przyjęty do seminarium w Rydze. W tym samym roku rozpoczął z grupą kandydatów konspiracyjne przygotowanie do kapłaństwa pod kierunkiem ks. Wacława Piątkowskiego w parafii Niedźwiedzica. Święce- 
przyjeżdżający do ks. Piątkowskiego kapłani pracujący w diecezji. Ponadto kandydaci owi uzupełniali swoją formację kapłańską i studia seminaryjne w seminarium w Rydze lub seminariach duchownych w Polsce ${ }^{73}$.

W parafii Niedźwiedzica ks. Piątkowski doczekał się złotego jubileuszu kapłaństwa, który świętował 27 i 28 IX 1981 roku. Za zasługi oddane Kościołowi w dziedzinie wiedzy i szerzenia Ewangelii Chrystusowej, papież Jan Paweł II w dniu 11 II 1988 roku mianował ks. Wacława protonotariuszem apostolskim infułatem. Kilka lat przed śmiercią jubilat zapisał: „Trwałem zdając się na Opatrzność ... Odczuwałem radość z wypełniania obowiązku”. W parafii Niedźwiedzica pracował ks. Piątkowski aż do śmierci. Zmarł 30 XI 1991 roku.

Zbudowana przez ks. Piątkowskiego kaplica na Kijówce w Brześciu przez prawie pół wieku była jedyną świątynią w tym mieście, po zamknięciu w połowie stycznia 1948 roku kościoła farnego w śródmieściu i kościoła Najświętszego Serca Jezusowego na Grajewskim Przedmieściu w 1949 roku oraz wszystkich kaplic szkolnych i szpitalnych. Miejsce to było duchową siłą pozostałej garstki wiernych, którzy po aresztowaniu w nocy z 28 na 29 VIII 1948 roku ks. Stanisława Łazara z Grajewki i podczas jego zesłania sami się modlili, nie zezwalając na jej zamknięcie.

Dzięki prowadzonej przez ks. Wacława Piątkowskiego kronice parafialnej, w której pisał o sobie w trzeciej osobie, poznajemy wiele inicjatyw, faktów, zagrożeń i szykan, których doświadczał i z którymi przyszło mu się zmierzyć jako kapłanowi.

nia kapłańskie otrzymał w wieku 20 lat, po otrzymaniu dyspensy papieskiej, w dniu 28 X 1980 roku z rąk bpa Vincentasa Sladkievičiusa. Po święceniach mieszkał w Derewnej, był zakrystianem i organistą. Ze względu na jawne praktyki religijne był wzywany na milicję, szantażowany i upokarzany, grożono mu nawet wysłaniem do Zakładu Reedukacji Społecznej. Po nieudanych próbach pozyskania do współpracy z KGB ks. Dziemianko otrzymał w 1982 roku powołanie do służby wojskowej. Przed wyjazdem ujawnił się jako kapłan. Po powrocie z wojska w maju 1984 roku został skierowany do Nowogródka, gdzie bez koniecznej „sprawki” potajemnie pełnił posługę kapłańską. W wyniku usilnych starań parafian u władz w Grodnie, Mińsku i Moskwie otrzymał w kwietniu 1985 roku „sprawkę” na parafię Nowogródek. Od września 1988 roku kierował odbudową kościołów we Wsielubiu, Niecieczy, Dworcu, Rohatnej i Worończy oraz drugiego kościoła (św. Michała Archanioła) w Nowogródku. W 1993 roku objął funkcję dyrektora „Caritas” powołanej już diecezji grodzieńskiej. Od 1995 roku pełnił funkcję dziekana nowogródzkiego. Dnia 4 VII 1998 roku Jan Paweł II mianował go biskupem pomocniczym diecezji grodzieńskiej. Jego konsekracji dnia 28 IX 1998 roku w Grodnie dokonał kard. Kazimierz Świątek. Dnia 14 XII 2004 roku mianowany został biskupem pomocniczym archidiecezji mińsko-mohylewskiej, a 14 VI 2006 roku z woli papieża Benedykta XVI bp Dziemianko mianowany został administratorem apostolskim sede vacante i ad nutum Sanctae Sedis tej archidiecezji do czasu mianowania metropolitą abpa Tadeusza Kondrusiewicza. Dnia 3 V 2012 roku został ordynariuszem diecezji pińskiej. Ingres do katedry odbył się 16 czerwca tego roku. Obecnie jest sekretarzem generalnym Konferencji Episkopatu Białorusi. Por. Dzwonkowski, Leksykon duchowieństwa polskiego, s. 212-214; Za wschodnia granica, s. 258.

${ }^{73}$ Por. Dzwonkowski, Leksykon duchowieństwa polskiego, s. 477; Za wschodnia granica, s. 258-259. 


\section{Modlitwa do Matki Bożej Brzeskiej/ Prayer to Our Lady of Brest}

Mato Boża Brzeska - Pani Ocalenia, łaski i miłosierdzia pełna.

Matko opuszczonych, Pociecho strapionych, Drogo błądzących,

Wspomożenie opieki potrzebujących, Matko nieustającego ratunku,

Racz ku wspomożeniu naszemu pośpieszyć.

Tchnij Ducha łaski Bożej w oziębłe serca naszych rodzin,

Ukaż miłość i radość życia z Bogiem.

Matko Boża Brzeska, przyczyń się za nami. Amen.

\section{Pieśń do Matki Bożej Brzeskiej \\ Matko Boża Brzeska - Pani Ocalenia/ \\ Hymn to Our Lady of Brest \\ God's Mother of Brest-Our Lady of Salvation}

1. Przed Tobą z wdzięcznością na kolana padamy

Matko Boża Brzeska, Matko ukochana.

Refren:Matko Boża Brzeska, Pani Ocalenia,

Do Ciebie śpieszymy w naszych utrapieniach.

Prowadź nas, o Matko, drogą nieskalaną,

Do Twojego Syna, do naszego Pana.

2. O Panno Najświętsza, zawsze nas Ty broniłaś,

Przyjm dziś nasze serca, przyjmij naszą miłość. Refren.

3. Tak nędznie tkwiliśmy długie lata w ciemności,

Lecz z nadzieją w sercach, z wiarą, cierpliwością. Refren.

4. Gdy Cię znieważano, świętą wiarę deptano, Przy Tobie trwaliśmy, Matko ukochana. Refren.

5. Ty dzieci swe Pani nigdy nie opuściłaś,

Siły nam dawałaś, z Bogiem jednoczyłaś. Refren.

6. Dla swoich czcicieli liczne cuda sprawiałaś,

Wątłe ludzkie dusze łaską uzdrowiłaś. Refren.

7. Chroń nas od niewiary, wspieraj w naszych zwątpieniach, Przyczyń się za nami, Matko Ocalenia. Refren. 
8. I żadna nam siła ani ziemska pokusa,

Wyrwać już nie zdoła z naszych serc Chrystusa. Refren.

9. O Matko, Twe serce Miłosierdzia skarbnicą,

Obdarz nas swą łaską, cudowna Dziewico. Refren.

10. Cudowny Twój Obraz nas od zguby ochrania, Matka Boża Brzeska, przyczyń się za nami. Refren.

słowa kluczowe: Brześć nad Bugiem, parafia Matki Bożej Królowej Korony Polskiej, diecezja pińska, II wojna światowa, ks. Wacław Piątkowski

\title{
THE ORIGINS OF THE PARISH OF OUR LADY QUEEN OF THE POLISH CROWN IN THE KIEV SUBURB IN BRZEŚĆ ON THE BUG
}

\begin{abstract}
Summary
Grassroots initiatives of the faithful of the city of Brześć, supported by the clergy, have been approved by the Ordinary of the Diocese of Pińsk - Bishop Zygmunt Łoziński, who on 16 October 1938 erected the parish in the Kiev Suburb in Brześć. For a growing number of the inhabitants of Brześć in the interwar period of the Second Polish Republic, the above- mentioned parish was established to meet the religious needs of the local Catholics. In August 1937, Rev. Wacław Piątkowski was mandated, by the Bishop of Pińsk, to create a parish with an indication of the Kiev Suburb, where he soon began celebrating daily liturgy in a temporary chapel.

Organized in November 1937, the Church Social Construction Committee undertook the care of raising funds for the implementation of a costly venture. A temporary chapel was consecrated on 14 August 1938 by Rev. Wacław Piątkowski, a parish priest. On 30 July 1939 the Bishop of Pińsk consecrated the foundation stone of the church, and next day the construction of the foundations began.

Until the outbreak of World War II, a concrete footing under the foundation of the church was made along with the necessary excavations. War and occupation: the Soviet and German prevented the implementation of the initiated project. During those years, priests performed pastoral service, not only in their own parishes but often helped other parishes which were deprived of priests because of the arrests of clergy and their deportation to concentration camps, as well as due to the moving of many priests to the west of the created in 1945 Polish-Soviet frontier on the Bug. Thanks to the clergymen who, despite everything, stayed after the war in the Diocese of Pińsk within the borders of Byelorussian SSR, the continuity of the hierarchical authority of the Church was preserved. That authority was exercised by the vicars general until the church administration had been organized within the borders of the Republic of Belarus.
\end{abstract}

keywords: Brest on the Bug, the Parish of Our Lady Queen of the Polish Crown, the Diocese of Pińsk, the Second World War, Rev. Wacław Piątkowski 